\title{
Estimating genetic variability among diverse lentil collections through novel multivariate techniques
}

Muhammad Sajjad lqbal ( $\nabla$ drsajjad.iqbal@uog.edu.pk)

Department of Botany, University of Gujrat, Gujrat,

Syed Atiq Hussain

Department of Botany, University of Gujrat, Gujrat,

Muhammad Akbar

Department of Botany, University of Gujrat, Gujrat,

Kashif llyas

Plant Genetics Resources Institute, National Agricultural Research Center, Islamabad,

\section{Abdul Ghafoor}

Plant Genetics Resources Institute, National Agricultural Research Center, Islamabad,

\section{Noshia Arshad}

Department of Botany, University of Gujrat, Gujrat,

Saba Munir

Department of Botany, University of Gujrat, Gujrat,

Muhammad Azhar Ali

Department of Botany, University of Gujrat, Gujrat,

Hajra Masood

Department of Botany, University of Gujrat, Gujrat,

Samina Zafar

Department of Botany, University of Gujrat, Gujrat,

Tahira Ahmad

Department of Botany, University of Gujrat, Gujrat,

Nazra Shaheen

Department of Botany, University of Gujrat, Gujrat,

Rizwana Mashooq

Department of Botany, University of Gujrat, Gujrat,

Hifsa Sajjad

Department of Botany, University of Gujrat, Gujrat,

Munaza Zahoor

Department of Botany, University of Gujrat, Gujrat,

Faiza Bashir

Department of Botany, University of Gujrat, Gujrat,

Khizra Shahbaz

Department of Botany, University of Gujrat, Gujrat,

Hamna Arshad

Department of Botany, University of Gujrat, Gujrat,

\section{Noor Fatima}

Department of Botany, University of Gujrat, Gujrat,

\section{Faiza Nasir}

Department of Botany, University of Gujrat, Gujrat,

Aysha Javed Hashmi

Department of Botany, University of Gujrat, Gujrat,

Sofia Chaudhary

Department of Botany, University of Gujrat, Gujrat,

Muhammad Islam

Department of Genetics, Hazara University, Mansehra,

\section{Research Article}

Keywords: genetic variability, lentil 
Posted Date: January 7th, 2021

DOl: https://doi.org/10.21203/rs.3.rs-135543/v1

License: @ (i) This work is licensed under a Creative Commons Attribution 4.0 International License. Read Full License 


\section{Abstract}

Lentil is a significant legume crop throughout the world where Pakistan stands at 18th position with 8610 tons from 17457 hectares. It is nutritionally rich in protein, carbohydrates, mineral, fat and fiber that can potentially meet food security resolving malnutrition issues. Lentil 220 collections representing Pakistan 184, Syria 14, USA 22 and 04 of unknown origin were studied for high yield, yield contributing traits and early cooking time. Results revealed high variability, 6122 (Pakistan) was considered as best during both years due to its performance as seed yield (68 \pm 1.7 ), biological yield (264 \pm 2.8 ), pod size (0.61 \pm 0.01 ), seed per pod (2), cooking time (11 minutes) and hard seed (0). Comparatively 6122 (Pakistan) and 6042 (Syria) produced the highest biological yield which could also be an efficient source for fodder. 5698 (Pak) and 6015 (USA) took 161-172 days in 2018 while 24783 (unknown) and 5561 (Pak) were matured early in 2019. Lowest cooking time 10 minutes was observed in 6074 and 5745 of Pakistani origin. Lentil with the lowest cooking time saves energy and resources, develops adequate flavor, texture and improves protein digestibility. Pearson correlation matrix, Principal component analysis, structural equational model, cluster analysis, heritability showed promising results. In conclusion 12 genotypes were selected on high yield potential and recommended for lentils breeding including 5664, 5687, 6084, 6062, 6122, 6058, 6087, 5689, 6042, 6074, Markaz 2009 \& Punjab 2009.

\section{Introduction}

Lentil (Lens culinaris Medik) is an annual, herbaceous, cool-season, autogamous (self-pollinated) and diploid legume with $4 \mathrm{Gbp}$ genome size ${ }^{1,2}$. It is domesticated with wheat and barley. One of the oldest dry legumes, about 9000 years ago from wild ancestors that initiated in the Near East and subsequently spread throughout Mediterranean Basin and Central Asia ${ }^{3}$. lentil is the 4 th crop in the world after bean, pea, and chickpea included seven taxa and four species that are L. culinaris, L. nigricans, L. ervoides, and L. lamottei, having two varietal types as macro-sperma (large seeded) and micro-sperma (small-seeded) ${ }^{4,5}$.

Lentils are consumed due to its third-highest level of protein contents, vitamins, and micronutrients that are a vital part of human nutrition while vegetative parts are being used as fodder for animals ${ }^{6}$. Protein found in lentil seed is of high quality which is about 22 to $35 \%$ of total seed mass and consists of a large number of main amino acids like lysine and isoleucine. Moreover, protein found in lentils is a source of low-cost protein in many regions of the world which is a usable source for human beings as well as animals ${ }^{7}$.

Along proteins lentils are good source of carbohydrates (59\%), minerals (2\%), and has very little fat and fiber playing a significant role to overcome malnutrition issues and deficiency of micronutrients in developing regions ${ }^{8}$. It is also the best source of iron, so it helps prevent iron deficiency ${ }^{9}$. Medicinally, it has low glycemic level so physicians strongly suggest for patients of diabetes, obesity and heart disorders ${ }^{9}$. Seeds of lentils are mucilaginous and laxative recommended for treating constipation, stomach infections, smallpox and ulcer ${ }^{6}$. Top ten lentil producing countries are Canada, India, Turkey, USA, Kazakhstan, Nepal, Australia, Russia, Bangladesh, and China ${ }^{10}$.

The imperative causes of low yield of lentil in Pakistan are cultivation on marginal lands with poor management practices, cultivation of local varieties, biotic and abiotic factors but the worse is adaptation of low yielding local genotypes in different environments due to low genetic varaibility ${ }^{11}$. For combating effects of biotic and abiotic stresses by application of herbicides, pesticides, and fertilizer as well as by improving irrigation systems are not cautiously practicable ${ }^{12}$. Best solution to this problem is to make superior planting material. In this regard plant breeding and modern biotechniques could improve crops by transferring a gene of interest. The insufficient information of genetic variability in existing lentil is major hindrance to getting highest potential of the crop and modern techniques as well ${ }^{13}$. Considering this, current studies were conducted to determine variation in agro-morphological traits among genotypes representing Pakistan, USA, and Syria.

Assessment of genetic diversity based on phenotypic markers has been conducted worldwide in the near past in lentil and other legumes ${ }^{3,7,11,14-18}$. Germplasm collections are valuable assets that possess a huge treasure of genetic material which can prove its worth in future crop improvement and development programs ${ }^{19}$. Genetic diversity can be estimated with the help of quantitative traits and qualitative as well ${ }^{20}$. A large number of morphometric techniques have been used to measure and classify genotypes based on genetic diversity as in pea, mungbean, alfalfa, black gram, soybean, and lentil in the near past. Likewise, current studies also used various statistical techniques pursuing the genetic diversity in the available genetic resources. This study was designed to evaluate diverse lentil collections for promising traits concerning qualitative and quantitative for consecutively two years focusing to identify novel material for starting lentil breeding program.

\section{Results}

\section{Descriptive statistics for agro-morphological traits}

Quantitative and qualitative descriptive statistics were performed for evaluation and characterization of lentil genotypes grown in 2018 and 2019 . Mean, variances, standard error of mean were analyzed for quantitative traits while frequency distribution was determined for qualitative traits. Results revealed that genotypes 6122 (Sheikhupura, Pak) was considered as the best genotypes based on quantitative traits. It performed best for 6 quantitative traits out of 12 that are Seed yield (68 \pm 1.7 ), biological yield $(264 \pm 2.8)$, pod size $(0.61 \pm 0.01)$, seed per pod (2), cooking time (11 minutes), Hard seed (0). Descriptive statistics for quantitative traits of lentil genotypes showed that mean \pm SE values of seed yield (30.08 $\pm 0.98 \mathrm{~g}$ ) were higher in 2018 as compared to seed yield ( $25.26 \pm$ $0.87 \mathrm{~g}$ ) in 2019 (Table 1). Check varieties showed reduced seed yield in 2019 as compared to yield of 2018.

Seed yield ranged from 5.0 to $85.00 \mathrm{~g}$ and 3.00 to $76.00 \mathrm{~g}$ in 2018 and 2019 respectively. Genotype 6084 (Narowal, Pak) depicted highest seed yield in 2018 $(85 \pm 0.07 \mathrm{~g})$ in $2019(76 \pm 2.9 \mathrm{~g})$. Whereas lowest seed yield $(5 \pm 0.5 \mathrm{~g})$ was noted in genotype 5475 (Gujranwala, Pak) in 2018 while during 2019 lowest seed yield ( $3 \pm 0.3 \mathrm{~g}$ ) was noted in 5494 (Okara, Pak) and 5475 (Gujranwala, Pak). Genotypes 6052 (Syria), 5583 (Muzaffargarh, Pak) and 5556 (Hyderabad, Pak) 
produced highest hundred seed weight $3.65 \mathrm{~g}, 3.64 \mathrm{~g}$ and $2.97 \mathrm{~g}$ respectively in 2018 whereas during 2019 genotypes 5583 (Muzaffargarh, Pak), 6052 (Syria) and 5684 (Narowal, Pak) produced $3.28 \mathrm{~g}, 3.2 \mathrm{~g}$ and $2.71 \mathrm{~g}$ hundred seed weight, respectively.

Table 1.

Descriptive statistics for quantitative traits of lentil grown in 2018 and 2019.

\begin{tabular}{|c|c|c|c|c|c|c|c|c|c|c|c|c|}
\hline \multicolumn{7}{|c|}{ During 2018} & \multicolumn{6}{|l|}{ During 2019} \\
\hline Traits & Mean & Min. & Max & $V(n)$ & SD & VC(n) & Mean & Min. & Max. & $V(n)$ & SD & $\operatorname{Vc}(n)$ \\
\hline SY & $30.08 \pm 0.9$ & 5 & 85 & 211 & 14.52 & 0.48 & $25.26 \pm 0.8$ & 3 & 76 & 166.8 & 12.91 & 0.51 \\
\hline HSW & $1.71 \pm 0.02$ & 1.05 & 3.65 & 0.12 & 0.35 & 0.2 & $1.68 \pm 0.01$ & 1.17 & 3.28 & 0.07 & 0.28 & 0.16 \\
\hline BY & $114.6 \pm 3.0$ & 42 & 264 & 1977 & 44.4 & 0.38 & $94.13 \pm 2.2$ & 34 & 187 & 1074 & 32.77 & 0.34 \\
\hline $\mathrm{PH}$ & $44.73 \pm 0.4$ & 27.38 & 71.12 & 47.08 & 6.86 & 0.15 & $46.7 \pm 0.4$ & 29.6 & 69 & 48.28 & 6.94 & 0.14 \\
\hline LPH & $14.97 \pm 0.1$ & 9.14 & 32.16 & 5.49 & 2.34 & 0.15 & $14.98 \pm 0.1$ & 10.72 & 33.34 & 4.15 & 2.03 & 0.13 \\
\hline PS & $0.3 \pm 0.0$ & 0.2 & 0.7 & 0.007 & 0.08 & 0.22 & $0.3 \pm 0.00$ & 0.2 & 0.7 & 0 & 0.08 & 0.22 \\
\hline SP & $2.00 \pm 0.0$ & 1 & 3 & 0.02 & 0.16 & 0.08 & $2.00 \pm 0.01$ & 1 & 3 & 0.08 & 0.28 & 0.14 \\
\hline MD & $184 \pm 0.3$ & 161 & 198 & 25.5 & 5.05 & 0.02 & $186 \pm 0.34$ & 161 & 198 & 25.5 & 5.05 & 0.02 \\
\hline CT & $14.55 \pm 0.1$ & 10 & 18 & 2.32 & 1.52 & 0.1 & $16.15 \pm 0.1$ & 10 & 18 & 2.32 & 1.52 & 0.1 \\
\hline HS & $0.37 \pm 0.0$ & 0 & 2 & 0.37 & 0.61 & 1.65 & $0.41 \pm 0.04$ & 0 & 2 & 0.37 & 0.61 & 1.65 \\
\hline NP & $2.04 \pm 0.0$ & 2 & 3 & 0.03 & 0.19 & 0.09 & $2.00 \pm 0.01$ & 1 & 3 & 0.02 & 0.16 & 0.08 \\
\hline
\end{tabular}

Mean \pm SE of biological yield for all genotypes was $114.6 \pm 3.0 \mathrm{~g}$ during 2018 while during 2019 it was $94.13 \pm 2.0$ g. Genotypes 6122 (Sheikhupura, Pak), 5689 (Sialkot, Pak), 5730 (Layyah, Pak), 6037 (Syria) produced highest biological yield $264 \pm 2.8 \mathrm{~g}, 258 \pm 1.0 \mathrm{~g}, 254 \pm 1.5 \mathrm{~g}$, and $254 \pm 2.0 \mathrm{~g}$ respectively in 2018. Whereas genotypes 6042 (Syria), 6087 (Narowal, Pak) and 5689 (Sialkot, Pak) produced highest biological yield i.e. $187 \pm 1.3 \mathrm{~g}, 183 \pm 0.9 \mathrm{~g}$ and $179 \pm$ $1.3 \mathrm{~g}$ respectively in 2019. Mean values \pm SE of plant height in $2018 \mathrm{had} 44.73 \pm 0.46 \mathrm{~cm}$ which was less than recorded in 2019 (46.7 $\pm 0.4 \mathrm{~cm}$ ). Genotype 5593 (Hyderabad, Pak) depicted highest plant height $(71.12 \pm 1.7 \mathrm{~cm}$ ) during 2018 while during 2019 genotype 6062 (Syria) had highest plant height (69.00 \pm $2.1 \mathrm{~cm}$ ). Genotypes originated from Pakistan showed best performance under conditions as compared to germplasm acquired from Syria and USA.

Mean value \pm SE of lower pod height during 2018 had $14.97 \pm 0.15 \mathrm{~cm}$ whereas during 2019 lower pod height had $14.98 \pm 0.13 \mathrm{~cm}$. Largest pod size attained a length of about $0.7 \pm 0.1 \mathrm{~cm}$ during 2018 whereas during 2019 it had $0.7 \pm 1.1 \mathrm{~cm}$. Mean values \pm SE of seeds per pod were $2.00 \pm 0.01$ in 2018 and similar results were also recorded in 2019. Genotypes 6074 (Bahawalnagar Pak), 5595 (Kharan, Pak), 6075 (Bahawalnagar, Pak) had $3.00 \pm 0.0$ seed per pod in 2018 while highest number of seed per pod (3.00 \pm 0.0 ) during 2019 were reflected by genotypes 5550 (Hyderabad, Pak), 5637 (Hyderabad, Pak), 5625 (Muzaffargarh, Pak), 5555 (Hyderabad, Pak), 5677 (Layyah, Pak), 5630 (Rajanpur, Pak), 5538 (Thatta, Pak), 5583 (Muzaffargarh, Pak), 5654 (Mianwali, Pak) and 5518 (Muzaffargarh, Pak). Days to maturity ranged from 161 to 198 days in 2018 and similar results were found in 2019 but mean values of days to maturity were $184 \pm 0.34$ during 2018 while $186 \pm 0.34$ during 2019. Highest days to maturity (196 to 198 days) was counted in 5684 (Narowal, Pak), 5988 (USA), 5979 (USA), 5679 (Narowal, Pak), 5982 (Narowal, Pak), 5683 (Narowal, Pak), 24786 (unknown), 5623 (Faisalabad), 6077 (Bahawalnagar, Pak) and 5684 (Narowal, Pak) while earliest maturing (161 to 178 days) genotypes 5698 (Sialkot, Pak), 6015 (USA), 5667 (Layyah, Pak), 5748 (Gujranwala, Pak), 5555 (Hyderabad, Pak), 6017 (USA), 5700 (Sialkot, Pak), 5571 (Jacobabad, Pak), 5580 (Ghotki, Pak), 5981 (USA) were recorded in 2018. Similar genotypes were also shown highest and lowest days to maturity in 2019.

Mean value of hard seeds was $0.37 \pm 0.04$ in 2018 and $0.41 \pm 0.04$ in 2019 . Highest number of hard seeds noted in 2018 and 2019 was 2 . Number of pods per peduncle ranged from 2 to 3 during 2018 and 1 to 3 during 2019. Mean value of the number of pods per peduncle in 2018 were $2.04 \pm 0.01$ whereas in 2019 was $2.00 \pm 0.01$. Two check varieties including Markaz 2009 and Punjab 2009 were also analyzed. Descriptive statistics of check varieties revealed that seed yield, hundred seed weight, and biological yield was higher in 2018 (Table 2) as compared to 2019 in both Markaz 2009 and Punjab 2009 varieties. Variance in seed yield (211), hundred seed weight (0.12), biological yield (1977), plant height (47.08), lower pod height (5.49), pod size (0.007), seed per pod (0.02), days to maturity (25.5), cooking time (2.32), hard seed (0.37) and number of pods per peduncle (0.03) were recorded in 2018. Traits with highest variance were biological yield (1977), seed yield (211) and plant height (47.08) in 2018. Whereas lowest variance in 2018 was recorded in pod size (0.007) and seed per pod (0.02). Similarly, biological yield (1074), seed yield (166.8) and plant height (48.28) were considered the highest variant traits in 2019 (Tables 1 and 2). 
Table 2

Best genotypes performed during 2018 and 2019 to specific traits. SY = seed yield, HSW = hundred seed weight, $\mathrm{BY}=$ biological yield, $\mathrm{PH}=$ plant height, $\mathrm{LPH}=$ lower pod height, $\mathrm{PS}=$ pod size, $\mathrm{SP}=$ seed per pod, $\mathrm{MD}=$ maturity day, $\mathrm{CT}=$ cooking time, $\mathrm{HS}=$ hard seed, $\mathrm{NP}=$ numbers of pod

\begin{tabular}{|c|c|c|}
\hline \multicolumn{3}{|c|}{ List of best genotypes during two years } \\
\hline Traits & During 2018 & During 2019 \\
\hline$S Y>40$ & $\begin{array}{l}6084,6062,6122,6058,6087,5689,6042,6074,5664,5687, \text { Markaz } \\
2009, \text { Punjab } 2009\end{array}$ & $\begin{array}{l}\text { 6084, } 6062,6122,6058,6087,5689,6074,6042,5664,5687, \text { Markaz } \\
\text { 2009, Punjab } 2009\end{array}$ \\
\hline $\begin{array}{l}\text { HSW > } \\
1.91\end{array}$ & $\begin{array}{l}6052,5583,5556,6101,6124,5684,5856,23776,6054,5643, \\
\text { Markaz 2009, Punjab 2009 }\end{array}$ & $\begin{array}{l}5583,6052,5684,6062,6101,5556,5643,5553,6086,2377 \text { Markaz } \\
\text { 2009, Punjab } 2009\end{array}$ \\
\hline $\begin{array}{l}\text { BY }> \\
87.5\end{array}$ & $\begin{array}{l}\text { 6122, 5689, 5730, 6037, 6042, 5600, 5653, 5982, 5658, 6084, Markaz } \\
\text { 2009, Punjab } 2009\end{array}$ & $\begin{array}{l}6042,6087,5689,6012,6037,6052,6060,24786,24783,6090 \\
\text { Markaz 2009, Punjab } 2009\end{array}$ \\
\hline $\begin{array}{l}\mathrm{PH}> \\
55.1\end{array}$ & $\begin{array}{l}5593,5549,5694,5687,5518,5472,5622,5500,5506,5723, \text { Markaz } \\
\text { 2009, Punjab } 2009\end{array}$ & $\begin{array}{l}6062,6067,6060,6074,5485,5562,6104,24783,5538,6064 \text {, Markaz } \\
\text { 2009, Punjab } 2009\end{array}$ \\
\hline $\begin{array}{l}\mathrm{LPH}> \\
15.6\end{array}$ & $\begin{array}{l}\text { 5527, } 6062,6013,6041,6042,5518,5686,5993,5529,6002 \text {, Markaz } \\
\text { 2009, Punjab } 2009\end{array}$ & $\begin{array}{l}\text { 6099, 5717, 5695, 6097, 5684, 6101, 6124, 6060, 5693, } 5667 \text { Markaz } \\
\text { 2009, Punjab } 2009\end{array}$ \\
\hline $\begin{array}{l}\text { PS }> \\
1.36\end{array}$ & $\begin{array}{l}6010,6013,6041,23776,6124,6122,6043,5996,6059,6076 \\
\text { Markaz 2009, Punjab } 2009\end{array}$ & $\begin{array}{l}5550,5556,5570,5667,5665,5661,5575,5531,5628,5623, \text { Markaz } \\
2009, \text { Punjab } 2009\end{array}$ \\
\hline $\mathrm{SP}>2$ & $\begin{array}{l}6074,5595,6075,6010,6013,6041,23776,6124,6122,6043, \\
\text { Markaz 2009, Punjab } 2009\end{array}$ & $\begin{array}{l}\text { 5550, 5637, 5625, 5555, 5677, 5630, 5538, 5583, 5654, 5518, Markaz } \\
\text { 2009, Punjab } 2009\end{array}$ \\
\hline $\begin{array}{l}\mathrm{DM}< \\
170\end{array}$ & $\begin{array}{l}5698,6015,5667,5748,5555,6017,5700,5571,5580,5981, \text { Markaz } \\
\text { 2009, Punjab } 2009\end{array}$ & $\begin{array}{l}\text { 6092, 6099, 5511, 5518, 5517, 6097, 6014, 5628, 5677, 6082, Markaz } \\
\text { 2009, Punjab } 2009\end{array}$ \\
\hline $\begin{array}{l}\text { CT }< \\
12.09\end{array}$ & $\begin{array}{l}6074,5595,6075,6010,6013,6041,23776,6124,6122,6043, \\
\text { Markaz 2009, Punjab } 2009\end{array}$ & $\begin{array}{l}6092,6099,5511,5518,5517,6097,6014,5628,5677,6082, \text { Markaz } \\
2009, \text { Punjab } 2009\end{array}$ \\
\hline $\mathrm{HS}<2$ & $\begin{array}{l}6074,5595,6075,6010,6041,23776,6124,6122,6043,5996, \\
\text { Markaz 2009, Punjab } 2009\end{array}$ & $\begin{array}{l}5529,5555,5636,5485,5553,5861,5677,5643,5856,5650, \text { Markaz } \\
\text { 2009, Punjab } 2009\end{array}$ \\
\hline$N P>2$ & $\begin{array}{l}\text { 5995, 5861, 5691, 5671, 6045, 5689, 5537, 5685, 6047, 6074, Markaz } \\
\text { 2009, Punjab } 2009\end{array}$ & $\begin{array}{l}5595,6075,6074,5480,5532,23779,5742,5637,5700,5694, \text { Markaz } \\
2009, \text { Punjab } 2009\end{array}$ \\
\hline
\end{tabular}

\section{Phenotypic traits data analysis}

Ground color of testa exhibit four categories out of which grey color showed highest frequency distribution (51.82\%) while brown (33.64\%), black (13.19\%) and green (1.37\%) ranked as second, third and fourth respectively during both years (2018 and 2019). Cotyledon color had the highest frequency ( $96.37 \%)$ of orange/ red color out of three categories during both years. Color of pattern on testa had five categories. Highest frequency (59.54\%) was recorded for category 2 (grey). Pod dehiscence was very low during both years. About $89.10 \%$ of lentil genotypes had low pod dehiscence frequency while high pod dehiscence was observed only in $0.90 \%$ genotypes. Other qualitative traits with frequency distribution are given in Table 3.

\section{Correlation Matrix (Pearson)}

Correlation matrix for 11 quantitative traits of lentil genotypes grown in 2018 revealed that seed yield showed a significant positive correlation with biological yield $\left(0.73^{*}\right)$, pod size $\left(0.32^{*}\right)$, seeds per pod $\left(1.50^{\star}\right)$ and number of pods per peduncles $\left(0.18^{\star}\right)$, as shown in Table 4 . Hundred seed weight exhibits a significant positive correlation with pod size $\left(0.29^{*}\right)$. Similarly, biological yield also showed a positive correlation with pod size $\left(0.34^{\star}\right)$. Whereas plant height and pod size showed a significant positive correlation with seed per pod $\left(0.17^{\star}\right)$ and maturity days $\left(0.15^{\star}\right)$ respectively. Whereas lentil genotypes grown in 2019 indicated that seed yield exhibits a significant positive correlation with a hundred seed yield $\left(0.27^{\star}\right)$, biological yield $\left(0.83^{\star}\right)$, plant height $\left(0.21^{\star}\right)$. Hundred seed weight also showed a positive correlation with biological yield $\left(0.31^{*}\right)$, similarly, biological yield showed a positive correlation with plant height $(0.16)$. Positive combinations and coordination describes high potential of the germplasm for its utilization in future crop improvement programs. 
Table 3

Frequency distribution of qualitative traits of lentil during 2018 and 2019

\begin{tabular}{|c|c|c|c|c|c|c|c|}
\hline Variable & $\begin{array}{l}\text { No. of } \\
\text { categories }\end{array}$ & $\begin{array}{l}\text { Categories } \\
\text { Name }\end{array}$ & $\begin{array}{l}\text { Frequency } \\
(\%)\end{array}$ & Variable & $\begin{array}{l}\text { No. of } \\
\text { categories }\end{array}$ & $\begin{array}{l}\text { Categories } \\
\text { name }\end{array}$ & $\begin{array}{l}\text { Frequency } \\
(\%)\end{array}$ \\
\hline \multirow[t]{4}{*}{ Ground color of testa } & 4 & Green & 1.36 & \multirow[t]{3}{*}{ Pod shedding } & 3 & Low & 59.54 \\
\hline & & Grey & 51.81 & & & Medium & 27.27 \\
\hline & & Brown & 33.63 & & & High & 13.18 \\
\hline & & Black & 13.18 & Tendril length & 1 & Prominent & 100 \\
\hline \multirow[t]{3}{*}{ Cotyledon color } & 3 & Yellow & 2.27 & Ground color of flower & 1 & $\begin{array}{l}\text { White blue } \\
\text { lines }\end{array}$ & 100 \\
\hline & & $\begin{array}{l}\text { Orange/ } \\
\text { red }\end{array}$ & 96.36 & \multirow[t]{3}{*}{ Leaflet size } & 3 & Small & 62.72 \\
\hline & & Olive-green & 1.36 & & & Medium & 28.18 \\
\hline \multirow{5}{*}{$\begin{array}{l}\text { Color of pattern on } \\
\text { testa }\end{array}$} & 5 & Absent & 0.90 & & & Large & 9.09 \\
\hline & & Olive & 7.72 & \multirow[t]{2}{*}{ Pod pigmentation } & 2 & Absent & 69.09 \\
\hline & & Grey & 59.54 & & & Present & 30.90 \\
\hline & & Brown & 13.63 & \multirow[t]{2}{*}{ Leaf pubescence } & 2 & Slight & 85 \\
\hline & & Black & 18.18 & & & Dense & 15 \\
\hline \multirow[t]{4}{*}{ Pod dehiscence } & 4 & None & 0.90 & \multirow{2}{*}{$\begin{array}{l}\text { Seedling stem } \\
\text { pigmentation }\end{array}$} & 2 & Absent & 69.09 \\
\hline & & Low & 89.09 & & & Present & 30.91 \\
\hline & & Medium & 9.09 & & & & \\
\hline & & High & 0.90 & & & & \\
\hline
\end{tabular}

Table 4.

Correlation matrix (Pearson) for quantitative traits of lentil grown in 2018 and 2019. 


\begin{tabular}{|c|c|c|c|c|c|c|c|c|c|c|c|}
\hline Traits & Years & HSW & BY & $\mathrm{PH}$ & LPH & PS & SP & MD & CT & HS & NP \\
\hline \multirow[t]{2}{*}{ SY } & 2018 & 0.09 & $0.73^{*}$ & -0.09 & 0.03 & $0.32^{\star}$ & $0.15^{\star}$ & 0.01 & -0.05 & 0.11 & $0.18^{*}$ \\
\hline & 2019 & $0.27^{*}$ & $0.83^{*}$ & $0.21^{*}$ & -0.11 & -0.11 & -0.11 & -0.05 & $-0.19^{*}$ & -0.01 & 0.08 \\
\hline \multirow[t]{2}{*}{ HSW } & 2018 & & 0.06 & -0.13 & -0.05 & $0.29 *$ & -0.04 & 0.05 & 0.04 & -0.09 & -0.01 \\
\hline & 2019 & & $0.31 *$ & 0.05 & -0.06 & -0.04 & 0.03 & -0.05 & -0.01 & -0.03 & -0.05 \\
\hline \multirow[t]{2}{*}{ BY } & 2018 & & & -0.02 & -0.04 & $0.34^{*}$ & 0.03 & 0.03 & -0.02 & 0.06 & 0.13 \\
\hline & 2019 & & & $0.16^{*}$ & $-0.16^{*}$ & -0.10 & -0.08 & -0.08 & -0.08 & -0.04 & 0.06 \\
\hline \multirow[t]{2}{*}{$\mathrm{PH}$} & 2018 & & & & 0.03 & -0.12 & $0.17^{*}$ & -0.04 & 0.06 & 0.06 & -0.06 \\
\hline & 2019 & & & & 0.12 & 0.05 & 0.01 & -0.12 & -0.05 & 0.06 & 0.05 \\
\hline \multirow[t]{2}{*}{ LPH } & 2018 & & & & & -0.07 & -0.02 & -0.09 & 0.03 & -0.06 & 0.02 \\
\hline & 2019 & & & & & -0.03 & -0.00 & 0.11 & -0.05 & 0.05 & -0.05 \\
\hline \multirow[t]{2}{*}{ PS } & 2018 & & & & & & 0.00 & $0.15^{\star}$ & 0.01 & -0.06 & -0.06 \\
\hline & 2019 & & & & & & 0.10 & -0.00 & 0.10 & -0.04 & -0.09 \\
\hline \multirow[t]{2}{*}{ SP } & 2018 & & & & & & & 0.00 & 0.07 & -0.04 & 0.00 \\
\hline & 2019 & & & & & & & 0.09 & 0.18 & -0.02 & 0.00 \\
\hline \multirow[t]{2}{*}{ DM } & 2018 & & & & & & & & 0.00 & -0.04 & 0.03 \\
\hline & 2019 & & & & & & & & -0.08 & -0.08 & 0.00 \\
\hline \multirow[t]{2}{*}{ СT } & 2018 & & & & & & & & & -0.04 & 0.03 \\
\hline & 2019 & & & & & & & & & $-0.13^{*}$ & -0.13 \\
\hline \multirow[t]{2}{*}{ HS } & 2018 & & & & & & & & & & 0.06 \\
\hline & 2019 & & & & & & & & & & 0.00 \\
\hline
\end{tabular}

\section{Principal Component Analysis (PCA)}

Principal component analysis based on the performance of traits studied in 2018 indicated that first five components have more than one eigenvalue such as $2.09,1.37,1.19,1.08,1.02$ for F1, F2, F3, F4, and F5 respectively, which have cumulative percentage up to 19.03, 31.54, 42.42, 52.33 and 61.67 (Table 5). Whereas other Principal components (F6 to F10) show less than 1 eigen value. Contribution of variables indicated that seed yield (35.15) biological yield (33.84) and pod size (19.37) represent highest F1 values whereas in F2 highest values were shown by hundred seed weight (23.41) plant height (15.62), and hard seed (13.26). Diverse genotypes have been divided into components that reflect PCA as an artificial tool for further selection of characters based on genetic variability. PCA indicated that the F1 component showed $19.05 \%$ total variation while F2 showed $12.51 \%$ total variation. Factors loading in F1 showed seed yield (0.84), biological yield (0.84), and number of pods per peduncle $(0.02)$ had highest values. While the F2 component showed highest factor loading with highest positive values for hundred seed weight (0.32), pod size (0.63) and maturity days (0.15). Total variation between F1 and F2 components was observed on PCA was $31.54 \%$ (Fig. 1). Selection can be made for individual as well as a whole principal component for improvement of crop.

Scattered diagram obtained from PCA analysis during 2018 indicated that lentil was classified into two factors i.e F1 and F2 (Fig. 2). F1 contributed 19.04\% variability and F2 indicated $12.19 \%$ variability. Following genotypes $(5638,5583,6124,6052,6010,5684,5979,6101)$ were noted to be present in the extreme upper left side of the scattered plot. Genotypes $(6054,5556,23776,5650)$ were placed at an extreme of the upper right side. Similarly, on the lower left side of scattered plot genotypes 6122, 6084, 5689, 5590 were present. Likewise, few genotypes viz., 5595, 5593, 55185549 showed their presence at extreme lower right side. Material with distinct output could be used for new combinations during breeding are suggested.

Similarly, principal component analysis of lentil genotypes grown in 2019 indicated that first five components have more than one eigen value such as 2.19 , $1.34,1.15,1.11,1.03$ for F1, F2, F3, F4, and F5 respectively, having cumulative percentage up to $19.91 \%, 32.10 \%, 42.62 \%, 52.78 \%$, and $62.67 \%$ respectively (Table 6). Remaining principal components (F6 to F10) show less than 1 eigen value. Contribution of variables indicated that SY (37.46) BY (36.51) and HSW (9.87) represent highest F1 values whereas in F2 highest values were shown by CT (31.77) SP (14.37) and HS (12.19). Separation of genotypes and their accumulation in the particular principal component indicates divergence like yield and yield contributing traits towards one PC that proves PCA a tool for further selection of characters for handling and crop improvement. PCA indicated that the F1 component showed $19.91 \%$ total variation while F2 showed $12.19 \%$ total variation. Total variation between F1 and F2 components was observed on PCA $32.10 \%$ (Fig. 3). 
Table 5

Principal component analysis for quantitative traits of lentil studied during 2018

\begin{tabular}{|lllllllllllll|l|}
\hline & F1 & F2 & F3 & F4 & F5 & F6 & F7 & F8 & F9 & F10 & F11 \\
\hline Eigenvalue & 2.09 & 1.37 & 1.19 & 1.08 & 1.02 & 0.95 & 0.89 & 0.80 & 0.76 & 0.57 & 0.23 \\
\hline Variability (\%) & 19.03 & 12.50 & 10.88 & 9.90 & 9.34 & 8.63 & 8.09 & 7.31 & 6.91 & 5.19 & 2.17 & 100 \\
\hline Cumulative \% & 19.03 & 31.54 & 42.42 & 52.33 & 61.67 & 70.30 & 78.39 & 85.71 & 92.62 & 97.82 & 100 \\
\hline Contribution of variables (\%) & & & & & & & & & \\
\hline & F1 & F2 & F3 & F4 & F5 & F6 & F7 & F8 & F9 & F10 & F11 \\
\hline SY & 35.15 & 6.56 & 0.06 & 0.56 & 0.50 & 0.24 & 0.03 & 0.69 & 0.20 & 5.30 & 50.65 \\
\hline HSW & 4.89 & 23.41 & 1.73 & 2.17 & 0.00 & 10.01 & 2.33 & 41.90 & 0.48 & 12.89 & 0.15 \\
\hline BY & 33.84 & 4.56 & 0.02 & 0.02 & 0.87 & 0.01 & 0.55 & 4.91 & 3.89 & 6.65 & 44.65 \\
\hline PH & 2.07 & 15.62 & 20.24 & 4.11 & 2.06 & 0.53 & 7.19 & 8.68 & 38.17 & 0.24 & 1.05 \\
\hline LPH & 0.33 & 3.01 & 0.00 & 51.58 & 2.12 & 4.49 & 25.60 & 6.59 & 5.44 & 0.24 & 0.56 \\
\hline PS & 19.37 & 11.21 & 2.96 & 0.27 & 2.64 & 0.91 & 2.42 & 0.00 & 0.00 & 60.18 & 0.01 \\
\hline SP & 0.45 & 8.64 & 35.05 & 0.88 & 0.01 & 5.98 & 17.71 & 4.00 & 24.71 & 0.44 & 2.09 \\
\hline MD & 1.10 & 7.98 & 2.06 & 16.08 & 16.97 & 20.89 & 28.48 & 0.43 & 1.71 & 4.22 & 0.03 \\
\hline CT & 0.11 & 0.00 & 19.90 & 6.22 & 23.84 & 30.67 & 2.95 & 14.79 & 0.96 & 0.40 & 0.12 \\
\hline HS & 0.25 & 13.26 & 11.02 & 15.05 & 0.02 & 24.41 & 7.63 & 9.61 & 17.83 & 0.39 & 0.50 \\
\hline NP & 2.40 & 5.70 & 6.94 & 3.03 & 50.93 & 1.83 & 5.06 & 8.37 & 6.56 & 8.99 & 0.15 \\
\hline
\end{tabular}

Table 6

Principal Component Analysis (PCA) for quantitative traits studied during 2019

\begin{tabular}{|lcccccccccccc|}
\hline & F1 & F2 & F3 & F4 & F5 & F6 & F7 & F8 & F9 & F10 & F11 \\
\hline Eigenvalue & 2.19 & 1.34 & 1.15 & 1.11 & 1.03 & 0.95 & 0.92 & 0.78 & 0.69 & 0.65 & 0.15 \\
\hline Variability (\%) & 19.91 & 12.19 & 10.52 & 10.16 & 9.37 & 8.65 & 8.41 & 7.13 & 6.30 & 5.90 & 1.42 \\
\hline Cumulative \% & 19.91 & 32.10 & 42.62 & 52.78 & 62.15 & 70.81 & 79.22 & 86.36 & 92.66 & 98.57 & 100 \\
\hline Contribution of variables (\%) & & & & & & & & & \\
\hline & F1 & F2 & F3 & F4 & F5 & F6 & F7 & F8 & F9 & F10 & F11 \\
\hline SY & 37.46 & 0.18 & 0.02 & 1.52 & 0.00 & 0.15 & 0.62 & 5.78 & 1.65 & 2.67 & 49.91 \\
\hline HSW & 9.87 & 7.68 & 0.00 & 1.89 & 6.70 & 10.36 & 1.16 & 56.41 & 0.00 & 5.80 & 0.07 \\
\hline BY & 36.51 & 2.26 & 0.20 & 0.43 & 0.02 & 0.03 & 0.09 & 6.02 & 3.70 & 1.79 & 48.90 \\
\hline PH & 4.26 & 0.57 & 41.65 & 3.35 & 6.62 & 6.10 & 1.17 & 0.42 & 14.59 & 21.09 & 0.13 \\
\hline LPH & 1.85 & 9.83 & 11.96 & 27.26 & 5.26 & 1.94 & 11.24 & 1.62 & 15.00 & 13.83 & 0.10 \\
\hline PS & 2.12 & 11.95 & 9.81 & 0.45 & 1.20 & 6.99 & 53.47 & 4.28 & 8.67 & 1.03 & 0.00 \\
\hline SP & 1.93 & 14.37 & 1.09 & 13.19 & 17.28 & 26.95 & 0.44 & 1.27 & 8.20 & 15.23 & 0.00 \\
\hline MD & 1.23 & 1.127 & 16.04 & 46.05 & 0.10 & 0.62 & 6.80 & 3.87 & 0.65 & 23.43 & 0.04 \\
\hline CT & 3.54 & 31.77 & 0.97 & 0.95 & 0.06 & 0.02 & 17.92 & 7.31 & 24.94 & 11.64 & 0.83 \\
\hline HS & 0.01 & 12.90 & 14.35 & 4.65 & 0.39 & 46.69 & 5.62 & 2.99 & 9.28 & 3.08 & 0.00 \\
\hline NP & 1.16 & 7.32 & 3.86 & 0.23 & 62.32 & 0.11 & 1.43 & 9.97 & 13.21 & 0.36 & 0.00 \\
\hline
\end{tabular}

Genotypes at extreme of upper left side of the scattered plot including $(5506,5729,5510,5672,5636,5581,5491,5483)$ while in lower left side genotypes $(5472,5512,5479,5486,5650,5600,5531)$ were placed at a lower extreme which showed wide variation in genotypes. Similarly, at upper right side of scattered plot, genotypes $(6080,6043,5653,6043,6002,6060$, and 5677) showed at extreme point while in lower right-side genotypes $23787,24787,23779$, 5742,5712 were placed at extreme variability point (Fig. 4).

Hierarchical cluster analysis 
The cluster analysis based on agro-morphological data (obtained in 2018) distributed 220 lentil genotypes into 4 main clusters at linkage distance (LD) of 14.5 (Fig. 5). Cluster C1 further subdivided at LD 9.4 into two sub-cluster i.e C2a and C2b. C2a have only one genotype (5698 Sialkot, Pak) while C2b further subdivided into two sub-clusters i.e., C2bi and C2bii. C2bi consisted of 32 genotypes whereas C2bii consisted of 51 genotypes. Cluster $\mathrm{C} 1$ further subdivided into two sub clusters i.e., C1a and C1b. C1a consist of only one genotype (6015 USA) while C1b further subdivided into C1bi having 32 genotypes and C1bii having 64 genotypes at LD 4.4. Cluster C3 consisted of two sub-clusters C3a and C3b at LD 9.4. Sub-cluster C3a consist of only 3 genotypes (5689 Sialkot, 5687 Narowal, 6084 Narowal) belonged to Pakistan while sub-cluster C3b further subdivided into C3bi and C3bii with 10 and 6 genotypes respectively. Cluster C4 also subdivided into two sub-clusters one is C4a having 6 genotypes and other is C4b with 3 genotypes at LD 9.4. Highest number of genotypes were found in cluster 1 (115genotypes) While C4 has lowest number of genotypes (9 genotypes) in 2018. The hierarchical dendrogram obtained from lentil agromorphological data (2019) indicated 7 main clusters named as C1, C2, C3, C4, C5, C6, and C7 at 50\% LD (8.4) (Fig. 6). Cluster C1 consisted of 37 genotypes while cluster C2 subdivided into two sub-clusters C2a and C2b. C2a consisted of 35 genotypes while C2b further subdivided into C2bi and C2bii. Sub-cluster C2bi consisted of 35 genotypes while sub-cluster C2bii consisted of only 4 genotypes (6099 Rawalpindi, 6092 Rawalpindi, 5511 Muzaffargarh, 5517 Muzaffargarh) of Pakistan origin. Cluster C4 consisted of only 12 genotypes whereas cluster C5 and C6 consisted of 1 (24783 of unknown origin) and 4 genotypes (6084 Narowal-Pak, 5056 Syria, 6062 Syria, and 6122 Sheikhupura-Pakistan) respectively. Cluster C6 consists of two sub-cluster i.e C6a and C6b with 17 and 32 genotypes. Cluster C7 consisted of only 2 genotypes (5664 Layyah and 6074 Bhawalnager) belonged to Pakistan.

\section{Structural Equational Model (SEM)}

Structural Equational Model (SEM) was built for seed yield (SY) based on covariance study as shown in Table 7. Seed yield was taken as a dependent variable whereas other traits such as SW, BY, PH, LPH, PS, MD, CT, HC, NP, and NSP were taken as independent variables (Fig. 7). Contribution of independent variables like LPH (P-values = 0.76), PS (P-values = 0.91), MD (P-values = 0.66), CT (P-values = 0.70), HC (P-values = 0.98), NP $(P$-values = 0.94), NSP $(P$-values = 0.93) observed significant (significant level $<1$ ) for yield as dependent variable which showed that relationship is perfect as indicated via SEM. This was further verified by lowest error variance of multiple linear regressions. Value of coefficient of determination $(R 2=0.683)$ of this multiple linear relationship supports this hypothesis that real yield contributors are given in equation.

\section{Heritability analysis}

Heritability is a statistical tool that estimates the degree of variation in phenotypic traits in a population based on genetic variation. Current studies revealed that heritability ranged from 0 to 1 . Heritability was highest for pod pigmentation (1), leaf pubescence (1), seedling stem pigmentation (1), leaf size (0.99), hundred seed weight (0.93), seed yield (0.87), biological yield (0.72), pod size (0.64), pod shedding 0.64 while heritability was low in cooking time 0.9 , and ground color of testa $\mathbf{0 . 1 7}$, while remaining traits had zero heritability. Values less than 1.00 elaborated that genes do not contribute at all to phenotypic individual differences whereas heritability values 1.00 mean genes are the only reason for individual differences (Table 8).

\section{Discussion}

Selection of best genotypes is always a thrusting search by scientists to develop cultivars for farmer's fields. Agro-morphological diversity has been used to characterize the genotypes in a range of plant species including lenti ${ }^{21}$. Wide variation was observed in lentil seed yield from 3-85 g with genotype 6084 Narowal (Pak), highest seed yield in $2018(85 \pm 0.07 \mathrm{~g})$ and $2019(76 \pm 2.9 \mathrm{~g})$ while previous studies showed $9.65 \mathrm{~g}$ maximum seed yield after studying 197 lentil genotypes ${ }^{16}$. Seed yield potential and variability offer breeders to develop high yielding cultivars with adopting varying environments ${ }^{22}$. Biological yield increases the photosynthetic area of the plants which enhance food quality and seed yield. In our study Genotypes 6122 Sheikhupura, 5689 Sialkot), 5730 (Layyah) of Pakistan origin and 6037 exhibited best biological yield during 2018. While genotypes 6042 (Syria), 6087 (Narowal, Pak) and 5689 (Sialkot, Pak) indicated best biological yield in 2019. Biological yield produced during 2018 and 2019 was higher and performed best (42-264 g/plant) as compared to previous studies biological yield ranged were $(2.04-19.22 \mathrm{~g} / \mathrm{plant})^{16}(5.43-40.07 \mathrm{~g})^{17}$, $(87.38 \mathrm{~g})^{23}$. Genetic variability in biological yield had a significant role in breeding program ${ }^{24}$. The improvement in biomass at the vegetative growth stage prior to flowering, leads to further increase in $\mathrm{N}$-assimilation and thereby in seed yield ${ }^{25,26}$.

Table 7.

Structural Equations of model

\begin{tabular}{|c|c|c|c|c|c|c|c|c|c|c|}
\hline SY & sw & BY & $\mathrm{PH}$ & LPH & PS & MD & CT & $\mathrm{HC}$ & NP & NSP \\
\hline Stander & 9606.03 & 9601.04 & 19202.89 & 1.89 & 202.65 & 0.10 & 2.68 & 18.19 & 30.82 & 21.85 \\
\hline Z-values & 0.00 & 0.00 & 0.000 & 0.31 & 0.11 & 0.43 & 0.39 & 0.02 & 0.07 & 0.08 \\
\hline P-values & 1 & 1 & 1 & 0.76 & 0.91 & 0.66 & 0.70 & 0.98 & 0.94 & 0.93 \\
\hline
\end{tabular}


Table 8

Heritability analysis of traits quantitative and average

performance of check varieties in divers 220 Lentil

\begin{tabular}{|llll|}
\hline \multicolumn{4}{|c}{ genotypes during 2018 and 2019} \\
\hline Variable & $\mathbf{V}_{\mathbf{G}}$ & $\mathrm{V}_{\mathrm{P}}$ & $\mathbf{h}^{2}$ bs \\
\hline Seed yield & 147.43 & 168.60 & 0.87 \\
\hline Hundred seed weight & 0.0902 & 0.09 & 0.93 \\
\hline Biological yield & 872.64 & 1,203 & 0.72 \\
\hline Plant height & 0.00 & 26.91 & 0.00 \\
\hline Lower pod height & 0.00 & 2.55 & 0.00 \\
\hline Pod size & 2.037 & 3.15 & 0.64 \\
\hline Seed per pod & 0.00 & 0.02 & 0.00 \\
\hline Maturity days & 0.00 & 13.20 & 0.00 \\
\hline Cooking time & 0.11 & 1.22 & 0.90 \\
\hline Hard seed & 0.00 & 0.21 & 0.00 \\
\hline Number of pods/peduncles & 0.00 & 0.01 & 0.00 \\
\hline Ground color of testa & 0.0519 & 0.2992 & 0.17 \\
\hline Cotyledon color & 0.0000 & 0.5371 & 0.00 \\
\hline Testa pattern color & 0.0000 & 0.2139 & 0.00 \\
\hline Pod dehiscence & 0.0320 & 0.3596 & 0.89 \\
\hline Pod shedding & 2.0370 & 3.1570 & 0.64 \\
\hline Tendril length & 0.0000 & 0.0000 & 0.0 \\
\hline Flower ground color & 0.0000 & 0.0000 & 0.0 \\
\hline Leaf size & 1.7103 & 1.7193 & 0.99 \\
\hline Pod pigmentation & 0.2145 & 0.2145 & 1.00 \\
\hline Leaf pubescence & 2.0493 & 2.0493 & 1.00 \\
\hline Seedling stem pigmentation & 0.2145 & 0.2145 & 1.00 \\
\hline
\end{tabular}

Seed yield and biological yield were higher in 2018 as compared to 2019 that probably due to temperature variation in both years. Average temperature was $21^{\circ} \mathrm{C}$ in March and $26^{\circ} \mathrm{C}$ in April during 2018 when the crop was getting mature while temperature was $19^{\circ} \mathrm{C}$ in March and $24^{\circ} \mathrm{C}$ in April during 2019 . Literature showed that optimum temperature for best lentil yield is $31.5^{\circ} \mathrm{C}$. Low temperature played significant role as reducing flowering and pod filling process and resultantly delay maturity. Lentil requires low temperature during vegetative stage, while the reproductive stage needs high temperatures ${ }^{27}$. Optimum temperature for vegetative stage of lentil ranged from 6.1 to $27.3^{\circ} \mathrm{C}$ while 17.4 to $31.5^{\circ} \mathrm{C}$ during reproductive stage $\mathrm{e}^{28}$. Genotype $5593 \mathrm{Hyderabad}$, Pak was recorded with highest plant height in $2018(71.12 \mathrm{~cm})$ while in 2019 genotype 6062 (Syria) had highest plant height (69 cm). Plant height of lentil reported in 2017 was ranged from $25.93-35.70 \mathrm{~cm}^{23}$ which is lower than recorded in current studies. Another study reported similar findings like 33.02 to $76.20 \mathrm{~cm}$ during $2018^{16}$. Plant height is a major yield contributing trait which support sufficient vegetative growth and branching provides an opportunity that ultimately develop sufficient number of pods and high contribution toward increased seed yield ${ }^{7,29}$. Time of maturity is considered as an important trait with its effective mechanism against drought, early maturity and seed set before onset of terminal drought is an important trait in grain legumes. In our study 5698 (Sialkot, Pak) and 6015 (USA), were considered as early maturing genotype with 161-172 days in 2018 while 24783 (unknown) and 5561 (Sanghar, Pak) were found early maturing 161-172 days during 2019 which is more appealing as compared to previous reports of 168-190 days. Development of early maturing cultivars is one of the breeding targets generally desired against drought in crops and in lentils, particularly ${ }^{30}$.

It is evident that seed yield is directly proportional to number of seeds per pod, higher the seed per pod higher will be seed yield. During current studies number of pods per peduncle ranged from 2-3 in 2018 and 1-3 in 2019. A constant variation in the number of pods per peduncle under different environmental conditions was also reported by various authors ${ }^{17}$.

Hundred seed weight is used as an indicator of seed quality and is a measure of grain bulk density. Our study showed that the highest hundred seed weight was $3.65 \mathrm{~g}$ in 2018 and $3.28 \mathrm{~g}$ in 2019 , coupled with a wide variation in both years. It was also noted that hundred seed weight was low in 2019 as compared to 2018 . Similar studies were also performed by various researchers to characterize and evaluate a wide range of crops including lentil $3,7,11,14-18$. 
Another aspect of lentils is lowest cooking time considered a favorite trait for consumers.in the current studies, lowest cooking time 10 mint has been observed in genotypes 6074 (Bahawalnagar, Pak) and 5745 (Faisalabad, Pak). Lentil with the lowest cooking time for grains saves energy and time, develops adequate flavor, texture and improves protein digestibility. While the highest cooking time causes proteins, vitamins, minerals and other secondary metabolites loss. Results showed that genotype 6122 (Sheikhupura, Pak) performed best out of 220 lentil genotypes based on quantitative traits. Therefore, suggested for further trails and breeding program for varietal development.

Grey ground color of testa and orange-red cotyledon color with grey color of pattern on testa was found in most genotypes. Various markets demand specific seed coat colors and/or patterns. We attempted to determine the percentage of color of testa, cotyledon color and color of pattern. Inheritance studies involving crosses between parental lines with various seed coat colors and patterns indicated that seed coat color is determined by two independent loci ${ }^{31}$. Pod pigmentation was absent in $69 \%$ genotypes with low Pod dehiscence and shedding. Low Pod dehiscence and shedding are considered most favorite traits in farmers perspective because low pod dehiscence and shedding reduce grain loss during harvesting. Slight leaf pubescence with a small leaf and prominent tendril was most frequently found. While dense pubescence only found in $15 \%$ of genotypes. Presence of dense leaf pubescence (leaf hairs) reduces absorbance of photosynthetically active radiation (400 to 700 nanometers). Reduction in photosynthetic rate is caused by decreased light absorption rather than decreased carbon dioxide conductance through boundary layer that is supported by Mohammed et al., ${ }^{17}$ who described that all studied genotypes had prominent tendril. It has been also reported that light leaf pubescence with a small leaf and prominent tendril exhibited high resistance to lodging. Furthermore, Stem pigmentation was present in most varieties. All genotypes exhibit white blue line flower ${ }^{32}$. Seedling stem pigmentation was absent in $69 \%$ of genotypes.

Improvement of a target character can be achieved by indirect selection via other characters that are more heritable and easier to select ${ }^{33}$. This strategy of selection requires understanding interrelationships among characters and with target character. A significant correlation between seed yield and most agromorphological traits was documented in both years 2018 and 2019. Seed yield showed a significant positive correlation with biological yield, pod size, seed per pod and number of pods per peduncles. Hundred seed weight exhibits a significant positive correlation with pod size in 2018 while in 2019 seed yield exhibits a significant positive correlation with a hundred seed yield, biological yield, and plant height. Seed yield per ha was mainly associated with increase in percentage of seed germination, pods per plant and seed index, while prolonged flowering and maturity of lentil crop reduces yield ${ }^{34,35}$. Number of pods per plant has a significant positive correlation with yield and yield contributing traits like biological yield \& hundred seed weight ${ }^{16} \cdot 36$.

PCA is an approach used statistically to distribute number of variables in data by extracting important one from a wide number of genotypes. Study showed that the first 5 components had eigenvalue $>1$. Contribution of variables toward traits revealed that seed yield, biological yield, and pod size had highest values in F1 which represent high variability among these traits whereas in F2 highest values were recorded in a hundred seed weight, plant height, and hard seed which are recommended for their future utilization. PCA was also recently performed by various authors who investigate genetic diversity in lentil genotypes natives of Pakistan and Turkey respectively ${ }^{16,17}$. PCs with eigenvalue $>1$ were considered in defining variability in genotypes which propose variation of genotypes were because of fairly high contribution of few traits rather than little contribution from each trait ${ }^{24}$. The application of PCA in an assortment of parental lines for breeding purposes has significant importance ${ }^{37}$. Scattered diagrams revealed that few genotypes were found at distinct positions during 2018 and 2019. Genotypes found in extreme showed high variation to other genotypes. The PC showed that seed yield, biological yield, pod size, hundred seed weight, plant height, and hard seed reflect these genotypes at extreme of scatter diagram. Previous studies showed more than $80 \%$ of genetic variation through the first two components ${ }^{37,38}$.

Hierarchical cluster analysis distributed genotypes based on genetic variation and performance of traits in both years. Genotype 6015 (USA) 5698 (Sialkot, Pak) showed an outlier from all other clusters in 2018 which indicated that this genotype performed differently and both genotypes showed best days to maturity. Genotypes 5664 (Sialkot, Pak) and 6074 (Bhawalnager, Pak) showed outliers from other clusters in 2019 and placed in cluster 7 . Genotypes 5664 and 6074 performed best for the maximum number of quantitative traits as well as seed yield. It was also recorded that Syria's native genotypes grouped into cluster 2 in 2019 while USA and Pakistan's native genotypes grouped together into different clusters. On the other hand genotypes of Syria, USA and Pakistan in 2018 grouped together in C2 clusters. Distribution of 220 lentil genotypes in both years in different clusters noted was probably due to effect of temperature at experimental site. Association among genotypes due to origin separated them from one another based on their genetic behaviour due to genetic variability and presence in the same cluster was due to low variation that could help to trace common ancestor. Considerable genetic variability can play significant role in any lentils breeding program as well as in the improvement of these traits through selection 24,40 . Large inter-cluster distance between members of any two clusters indicates that genotypes falling in such clusters would be more genetically divergent. Cluster analysis is the best tool to identify the genetic diversity and they classified the 220 lentil genotypes into different clusters based on agro-morphological data as well ${ }^{41}$. Generally, genotypes within a group showed little divergence from each other than from genotypes of different groups as has been observed in previous studies ${ }^{42,43}$.

Structural Equation Model provides a natural vehicle to analyze such complex "multivariate experiments". In our study SEM showed significant level < 1 contribution of independent variables like lower pod height, pod size, days to maturity, cooking time, hard seed number of pods, number of seeds per pods toward seed yield as dependent variable. SEM analysis applied to evaluate relationships of seed yield with other dependent variables. To attain desirable yield potential, it is essential to identify major components that have collective impact on total grain yield ${ }^{16}$.

Heritability was highest for pod pigmentation followed by leaf pubescence, seedling stem pigmentation, leaf size, hundred seed weight, seed yield, biological yield, pod size, pod shedding while heritability was low in cooking time, ground color of testa. Highest broad-sense heritability was noted for seed yield per plant and number of pods per plant ${ }^{44}$. Most agro-morphological traits had fairly more heritability ${ }^{18}$. It is assumed that a greater advance under selection is achieved when characters under selection are highly heritable and stable. Therefore, characters with high heritable value are much more important to a plant breeder than those which are less heritable could enable to develop new combinations for crop improvement programs ${ }^{45}$. 


\section{Conclusion}

Genotype 6122 originated from Sheikhupura, Pakistan presents best results during both years therefore recommended for farmers field cultivation after conducting necessary trials. As far as biological yield was concerned, genotypes representing Pakistan and Syria exhibited best values for biological yield. Pod pigmentation was absent in $69 \%$ genotypes with low Pod dehiscence and shedding that attracts farmers due to harvesting grain losses. Pearson correlation matrix showed significant association among various traits during both years that could contribute to future crop improvement programs to obtain bumper varieties. Highest eigenvalues were shown by F1 2.09 (2018) and F1 2.19 (2019) while studying PCA. Likewise structural equational model displayed

significant level < 1 contribution of independent variables (LPH, PS, MD, CT, HS, NP, NSP) toward seed yield as dependant variable. Cluster analysis revealed 04 clusters during 2018 and 07 in 2019 based on quantitative traits revealed geographic distribution independent of origin. Heritability was highest for pod pigmentation, leaf pubescence, seedling stem pigmentation, leaf size, hundred seed weight, seed yield, biological yield, pod size, pod shedding. Twelve genotypes including 5664, 5687, 6084, 6062, 6122, 6058, 6087, 5689, 6042, 6074, Markaz 2009 \& Punjab 2009 were selected based on high yield and recommended for future crop improvement programs.

\section{Material And Methods}

\section{Plants material}

Two hundred and twenty lentil collections from Pakistan, USA and Syria were obtained from National Gene Bank, Plant Genetic Resource Institute, National Agriculture Research Center (NARC), Islamabad, Pakistan (Table 9).

Study site, Research Design and Crop Cultivation

Agro-morphological traits were assessed under field conditions of NARC in Islamabad, Pakistan located at $33.6701^{\circ} \mathrm{N}$ latitude North and $73.1261^{\circ} \mathrm{E}$ longitude East, during two consecutive years (2018 and 2019). Monthly temperatures during these years were recorded as is provided in Fig. 8. Experiments were laid out in an augmented design ${ }^{16}$. In each year, genotypes were sown on a line of $5 \mathrm{~m}$ length, with $10 \mathrm{~cm}$ space between plants and $30 \mathrm{~cm}$ line to line (row) spacing. Two known cultivars, viz., Markaz 2009 and Punjab 2009, were planted as check (control) after every twenty lines. Recommended cultural practices were followed throughout the crop season. 
Table 9

List of lentil genotypes studied during 2018-19.

\begin{tabular}{|c|c|c|c|c|c|c|c|c|c|}
\hline Obs & Genotypes & Origin & Obs & Genotypes & Origin & & Genotypes & Origin & \\
\hline 1 & 5472 & Sialkot & 24 & 5511 & Muzaffargarh & 47 & 5571 & Jacobabad & 70 \\
\hline 2 & 5474 & Gujranwala & 25 & 5512 & Muzaffargarh & 48 & 5575 & Ghotki & 71 \\
\hline 3 & 5475 & Gujranwala & 26 & 5517 & Muzaffargarh & 49 & 5576 & Ghotki & 72 \\
\hline 4 & 5476 & Gujranwala & 27 & 5518 & Muzaffargarh & 50 & 5580 & Muzaffargarh & 73 \\
\hline 5 & 5477 & Gujranwala & 28 & 5527 & Sialkot & 51 & 5581 & Multan & 74 \\
\hline 6 & 5478 & Sheikhupura & 29 & 5529 & Kasur & 52 & 5583 & Muzaffargarh & 75 \\
\hline 7 & 5479 & Lahore & 30 & 5530 & Muzaffargarh & 53 & 5584 & Muzaffargarh & 76 \\
\hline 8 & 5480 & Kasur & 31 & 5531 & Muzaffargarh & 54 & 5590 & Muzaffargarh & 77 \\
\hline 9 & 5481 & Kasur & 32 & 5532 & Jhang & 55 & 5593 & Nawabshah & 78 \\
\hline 10 & 5482 & Lahore & 33 & 5535 & Jhang & 56 & 5595 & Kharan & 79 \\
\hline 11 & 5483 & Sheikhupura & 34 & 5537 & Gujrat & 57 & 5598 & Kharan & 80 \\
\hline 12 & 5484 & Sheikhupura & 35 & 5538 & Thatta & 58 & 5600 & Punjgur & 81 \\
\hline 13 & 5485 & Kasur & 36 & 5549 & Badin & 59 & 5610 & Khuzdar & 82 \\
\hline 14 & 5486 & Kasur & 37 & 5550 & Hyderabad & 60 & 5621 & Faisalabad & 83 \\
\hline 15 & 5488 & Okara & 38 & 5553 & Hyderabad & 61 & 5622 & Faisalabad & 84 \\
\hline 16 & 5489 & Okara & 39 & 5555 & Hyderabad & 62 & 5623 & Faisalabad & 85 \\
\hline 17 & 5491 & Sahiwal & 40 & 5556 & Hyderabad & 63 & 5624 & Rawalpindi & 86 \\
\hline 18 & 5493 & Sahiwal & 41 & 5561 & Sanghar & 64 & 5625 & Muzaffargarh & 87 \\
\hline 19 & 5494 & Okara & 42 & 5562 & Sanghar & 65 & 5626 & Muzaffargarh & 88 \\
\hline 20 & 5500 & Khanewal & 43 & 5563 & Sanghar & 66 & 5628 & Rajanpur & 89 \\
\hline 21 & 5501 & Khanewal & 44 & 5564 & Sanghar & 67 & 5630 & Rajanpur & 90 \\
\hline 22 & 5506 & Muzaffargarh & 45 & 5565 & Hyderabad & 68 & 5634 & Layyah & 91 \\
\hline 23 & 5510 & Muzaffargarh & 46 & 5570 & Larkana & 69 & 5635 & Larkana & 92 \\
\hline 116 & 5696 & Narowal & 139 & 5751 & Jhelum & 162 & 6015 & USA & 185 \\
\hline 117 & 5698 & Sialkot & 140 & 5753 & Rawalpindi & 163 & 6017 & USA & 186 \\
\hline 118 & 5700 & Sialkot & 141 & 5772 & Panjgur & 164 & 6037 & Syria & 187 \\
\hline 119 & 5712 & Narowal & 142 & 5773 & Kharan & 165 & 6038 & Syria & 188 \\
\hline 120 & 5716 & Narowal & 143 & 5856 & USA & 166 & 6041 & Syria & 189 \\
\hline 121 & 5717 & Gujranwala & 144 & 5861 & USA & 167 & 6042 & Syria & 190 \\
\hline 122 & 5723 & Layyah & 145 & 5979 & USA & 168 & 6043 & Syria & 191 \\
\hline 123 & 5724 & Layyah & 146 & 5981 & USA & 169 & 6045 & Syria & 192 \\
\hline 124 & 5726 & Layyah & 147 & 5982 & USA & 170 & 6046 & Syria & 193 \\
\hline 125 & 5727 & Layyah & 148 & 5988 & USA & 171 & 6047 & Syria & 194 \\
\hline 126 & 5729 & Layyah & 149 & 5993 & USA & 172 & 5856 & USA & 195 \\
\hline 127 & 5730 & Layyah & 150 & 5995 & USA & 173 & 6052 & Syria & 196 \\
\hline 128 & 5737 & Chakwal & 151 & 5996 & USA & 174 & 6054 & Syria & 197 \\
\hline 129 & 5739 & Muzaffargarh & 152 & 5999 & USA & 175 & 6058 & Syria & 198 \\
\hline 130 & 5741 & Bahawalpur & 153 & 6002 & USA & 176 & 6060 & Syria & 199 \\
\hline 131 & 5742 & Bahawalpur & 154 & 6003 & USA & 177 & 6062 & Syria & 200 \\
\hline 132 & 5744 & Faisalabad & 155 & 6005 & USA & 178 & 6064 & Syria & 201 \\
\hline 133 & 5745 & Faisalabad & 156 & 6008 & USA & 179 & 6066 & Bahawalpur & 202 \\
\hline
\end{tabular}




\begin{tabular}{|c|c|c|c|c|c|c|c|c|c|c|}
\hline Obs & Genotypes & Origin & Obs & Genotypes & Origin & Obs & & Genotypes & Origin & \\
\hline 134 & 5746 & Lahore & 157 & 6010 & USA & & 180 & 6067 & Bahawalpur & 203 \\
\hline 135 & 5747 & Kasur & 158 & 6011 & USA & & 181 & 6068 & Bahawalpur & 204 \\
\hline 136 & 5748 & Gujranwala & 159 & 6012 & USA & & 182 & 6069 & Bahawalpur & 205 \\
\hline 137 & 5749 & Gujranwala & 160 & 6013 & USA & & 183 & 6073 & Bahawalnagar & 206 \\
\hline 138 & 5750 & Jhelum & 161 & 6014 & USA & & 184 & 6074 & Bahawalnagar & 207 \\
\hline
\end{tabular}

\section{Data Collection}

Two categories of data, quantitative and qualitative were recorded. For quantitative traits, at late vegetative stage ten healthy plants were selected randomly for recording plant height (PH), number of pods per peduncle (NP), lower pod height (LPH), pod size (PS), number of seeds per pod (NSP), and days to maturity (DM) were recorded on foliage, reproductive and at maturity stages. Days to maturity were counted as from sowing day to turning of pods into golden brown of pods (90\%). After harvesting biological yield (BY), seed yield (SY), hundred seed weight (HSW), cooking time (CT) [time measured in minutes for cooking unsoaked seed to softness in boiling distilled water at atmospheric pressure] and hard seeds (HS) after boiling 100 seeds were counted.

For qualitative traits, investigations were based on direct observations with categories defined for each trait as mentioned in Table 3. At a late vegetative stage, seedling stem pigmentation, leaflet size and leaf pubescence were observed. At an early reproductive stage, flower ground color was observed. Flower ground color was rated from 1 to 6 according to color shade. 1 indicated white color, 2; white with blue lines, 3; blue, 4; violet, 5; pink, and 6; other. At late reproductive stage, pod pigmentation was observed. At maturity stage, pod dehiscence and pod shedding were surveyed. Pod dehiscence rated from 0 to 7 dehiscence rate. Pod shedding is also rated from 0 to 7 . Tendril length was also observed during late reproductive stage. After harvesting, color of pattern on testa, cotyledon color and ground color of test were observed. Color of pattern on testa rated 0 to 4 according to color of pattern. Cotyledon color rated 1 to 3 according to color.

\section{Statistical Analysis}

"XLstat 2019" was used to analyze quantitative and qualitative traits data, by which frequency distribution of qualitative traits, Pearson correlation, and PCA analysis were performed. RStudio2019 was explored for hierarchical cluster analysis while "LISREL 10" was employed for regression analysis and Structural Equational Model. Heritability of qualitative and quantitative traits was determined by consulting an online tool "PBSTAT".

\section{Declarations}

\section{Competing interest:}

No

\section{References}

1. Ates, D., Aldemir, S., Yagmur, B., Kahraman, A., Ozkan, H., Vandenberg, A., \& Tanyolac, M. B. QTL mapping of genome regions controlling manganese uptake in lentil seed. G3, 8(5), 1409-1416 (2018).

2. Ates, D. Genetic diversity in lentil landraces revealed by diversity array technology (DArT). Turkish J. Field Crops24(2), 252-260.

3. Scippa, G. S., Trupiano, D., Rocco, M., Viscosi, V., Di Michele, M., D'andrea, A., \& Chiatante, D. (2008). An integrated approach to characterization of two autochthonous lentil (Lens culinaris) landraces of Molise (south-central Italy). Heredity, 101(2), 136-144.

4. Thavarajah, P. (2012). Evaluation of chickpea (Cicer arietinum) micronutrient composition: Biofortification opportunities to combat global micronutrient malnutrition. Food Res. Intern.49(1), 99-104.

5. Mbasani-Mansi, J., Briache, F. Z., Ennami, M., Gaboun, F., Benbrahim, N., Triqui, Z. E. A., \& Mentag, R. (2019). Resistance of Moroccan lentil genotypes to Orobanche crenataJ. Crop Improve. 33(3), 306-326.

6. Pandey, S., \& Bhatore, A. (2018). Genetic diversity analysis for quantitative traits in indigenous genotypes of lentil in Madhya Pradesh. Pharmacog. Phytochem.7(1), 279-283.

7. Gaad, D., Laouar, M., Abdelguerfi, A., \& Gaboun, F. (2018). Collection and agro morphological characterization of Algerian accessions of lentil (Lens culinaris). Biodiversitas J. Biol. Divers.19(1), 183-193.

8. Srivastava, R. P., \& Vasishtha, H. (2012). Saponins and lectins of Indian chickpeas (Cicer arietinum) and lentils (Lens culinaris). Indian J. Agri. Biochem.25(1), 44-47.

9. Kumar, J., Gupta, S., Dubey, S., Gupta, P., Gupta, D. S., \& Singh, N. P. (2018). Genetic diversity changes in Indian lentils over times. plant biochem. Biotech.27(4), 415-424.

10. FAOSTAT (2019) http://www.fao.org/faostat/en/\#data. Accessed 26 March 2019.

11. Noor, R., Khan, S. M., Ahmad, F., Hussain, M., Abd_Allah, E. F., Alqarawi, A. A., \& Aldubise, A. (2017). morpho-agronomic characterization study of Lens culinaris genotypes under salt marsh habitat in Swat, Pakistan. Saudi J. Biol. Sci.24(7), 1639-1645.

12. Ghafoor, A., \& Arshad, M. (2008). Seed protein profiling of Pisum sativum, genotypes using sodium dodecyl sulphate polyacrylamide gel electrophoresis (SDS-PAGE) for investigation of biodiversity. Pak. J. Bot.40(6), 2315-2321. 
13. Ullah, J. A. M. I. L., Shah, A. H., Nisar, Muhammad., Khan, W., Khan, U., Khan, J., \& Ahmad, H. (2016). Biochemical characterization of lentil genotypes for genetic diversity. Plant Cell Biotech. Mol. Biol.17, 7-13.

14. Gupta, R., Begum, S. N., Islam, M. M., \& Alam, M. S. (2012). Characterization of lentil (Lens culinaris) genotypes through phenotypic marker. J. Bangladesh Agri. Uni.10(2), 197-204.

15. Cristobal, M. D., Pando, V., \& Herrero, B. (2014). Morphological characterization of lentil (Lens culinaris) landraces from Castilla y León, Spain. Pak. J. Bot.46(4), 1373-1380.

16. Bilal, M., Jamil, M., Ali, A., llyas, M. K., \& Ghafoor, A. (2018). Multivariate analysis of genetic diversity in lentil (Lens culinaris) germplasm. Environ. Bull. 27(4), 2151-2159.

17. Mohammed, N. A., Refay, Y. A., Migdadi, H. M., AL-Somain, B. H., Muharram, A. A., Al-Selwey, W. A., \& Farooq, M. (2019). Agro-Morphological Characterization of Lentil Genotypes in Dry Environments. J. Agri. Biol. 22(6), 1320-1330.

18. Naoura, G., Sawadogo, N., Atchozou, E. A., Emendack, Y., Hassan, M. A., Reoungal, D., \& Laza, H. (2019). Assessment of agro-morphological variability of dry-season sorghum cultivars in Chad as novel sources of drought tolerance. Scientific Rep.9(1), 1-12.

19. Sinha, A. K., \& Mishra, P. K. (2013). Agro-morphological characterization and morphology-based genetic diversity analysis of landraces of rice variety (Oryza sativa) of Bankura district of West Bengal. Intern. J. Curr. Res.5(10), 2764-2769.

20. Ghafoor, A., Sharif, A., Ahmad, Z., Zahid, M. A., \& Rabbani, M. A. (2001). Genetic diversity in blackgram (Vigna mungo Hepper). Field Crops Res.69(2), 183190.

21. Hussain, N., Yaqoob, M., \& Rashid, A. (2014). Genetic competition among lentil (Lens culinaris) candidate lines for yield and yield components under rainfed conditions. Agri. Res.52(1).

22. Iqbal, M. S., Ghafoor, A., Abbasi, F. M., Qureshi, A. S., \& Ahmad, H. (2011). Study of nutritional characteristics, mineral nutrients and agro-biodiversity in black cumin (Nigella sativa) genotypes from Pakistan. Afri. J. Biotech.10(66), 14757-14766.

23. Paliya, S., Saxena, A., Tikle, A. N., Singh, M., \& Tilwari, A. (2015). Genetic divergence and character association of seed yield and component traits of lentil (Lens culinaris). Adv. Biores.6(2), 53-59.

24. Bhartiya, A., Aditya, J. P., \& Singh, S. (2015). Assessment of variability for agro-morphological traits in elite lentil (Lens culinaris) lines using multivariate analysis. Indian J. Agri. Res. 49(6), 539-543.

25. Whitehead, S., R. Summerfield, F. Muehlbauer, C. Coyne, R. Ellis and T. Wheeler, 2000. Crop improvement and the accumulation and partitioning of biomass and nitrogen in lentil. Crop Sci., 40: 110-120.

26. Blumenthal, J. M., Baltensperger, D. D., Cassman, K. G., Mason, S. C., \& Pavlista, A. D. (2008). Importance and effect of nitrogen on crop quality and health. Agronomy \& Horticulture. Faculty Publications. 200. Published in Nitrogen in the Environment: Sources, Problems, and Management, Second edition, edited by J. L. Hatfield and R. F. Follett (Amsterdam: Elsevier, 2008). 51-70).

27. Roy, S., Islam, M. A., Sarker, A., Ismail, M. R., Rafii, M. Y., Mondal, M. M. A., \& Malek, M. A. (2012). Morphological characterization of lentil accessions: Qualitative characters. Bangladesh J. Bot.41(2), 187-190.

28. Sita, K., Sehgal, A., Kumar, J., Kumar, S., Singh, S., Siddique, K. H., \& Nayyar, H. (2017). Identification of high-temperature tolerant lentil (Lens culinaris Medik.) genotypes through leaf and pollen traits. Plant Sci.8, 744.

29. Kumar, S., Hamwieh, A., Manickavelu, A., Kumar, J., Sharma, T. R., \& Baum, M. (2014). Advances in lentil genomics. In: Legumes in Omic EraGupta S, Nadarajan N, Gupta DS. Springer Science+Business Media, New York, USA. 111-130.

30. Thomson, B. D., Siddique, K. H. M., Barr, M. D., \& Wilson, J. M. (1997). Grain legume species in low rainfall Mediterranean-type environments I. Phenology and seed yield. Field Crops Res.54(2-3), 173-187.

31. Vandenberg, A., \& Slinkard, A. E. (1990). Genetics of seed coat color and pattern in lentil. J Hered. 81(6), 484-488.

32. Dixit, G. P., Katiyar, P. K., \& Singh, B. B. (2011). Characterization of lentil (Lens culinaris) varieties based on morphological traits. J. Food Leg.24(3), 194197.

33. Dugassa, A., Legesse, H., \& Geleta, N. (2015). Genetic variability, yield and yield associations of lentil (Lens culinaris) genotypes grown at Gitilo Najo, Western Ethiopia. Sci. Tech. Arts Res. J.3(4), 10-18.

34. Depar, M. S., Soomro, N. A., Chandio, A. S., Samoon, H. A., Meghwar, B. L., Pathan, A. K., \& Kalroo, M. W. (2016). Evaluation of morpho-yield traits and their correlation with seed yield in lentil (Lens culinaris) genotypes. Intern.28(3).

35. Abo-Hegazy, S. R. E., Selim, T., \& El-Emam, E. A. A. (2012). Correlation and path coefficient analyses of yield and some yield components in lentil. Egyptian J. Plant Breed.203(1127), 1-14.

36. Shrestha, J., \& Subedi, S. (2019). Improving crop productivity through sustainable intensification. South Asian Res. J. Agri. Fish.1(1), 8-11.

37. Afuape, S.O., Okocha P.I. and Njoku, D. (2011). Multivariate assessment of the agro morphological variability and yield components among sweet potato (Ipomoea batatas (L.) Lam) landraces. African J. Plant Sci. 5: 123-132.

38. Benbrahim, N., M.Taghouti, A. Zouahri and F. Gaboun. 2017. On-farm conservation of Zaer lentil landrace in context of climate change and improved varieties competition. J. Agric. Res. 5(1): 27-38.

39. Idrissi, O., A. Piergiovanni, F. Toklu, C. Houasli, S. Udupa, E. De Keyser and J. De Riek. 2018. Molecular variance and population structure of lentil (Lens culinaris) landraces from Mediterranean countries as revealed by simple sequence repeat DNA markers: Implications for conservation and use. Plant Genet. Resour. 16(3): 249-259

40. Bharawadraj, Ch., C. T. Satyavath and D. Subramanyam. (2001). Evaluation of different classificatory analysis methods in some rice (Oryza sativa) collections. Ind. J. Agric. Sci. 71(2): 123-125.

Page 15/21 
41. Nath, U. K., Rani, S., Paul, M. R., Alam, M. N., \& Horneburg, B. (2014). Selection of superior lentil (Lens esculenta) genotypes by assessing character association and genetic diversity. The Sci. World J. p 6. http://dx.doi.org/10.1155/2014/372405.

42. Tyagi, S. D., \& Khan, M. H. (2010). Studies on genetic variability and interrelationship among different traits in Microsperma lentil (Lens culinaris). J. Agri. Biotech. Sustain. Devel. 2(1), 15.

43. Asghar, M.J., Abbas, G., Shah, T.M., Atta, B.M. (2010). Study of genetic diversity in some local and exotic lentil (Lens culinaris Medik) genotypes. J. Bot. 42(4):2681-2690.

44. Bicer, B. T., \& Sakar, D. (2010). Heritability of yield and its components in lentil (Lens culinaris). Bulgarian J. Agri. Sci. 16(1), 30-35.

45. Tambal, H. A. A., Erskine, W., Baalbaki, R., \& Zaiter, H. (2000). Relationship of flower and pod numbers per inflorescence with seed yield in lentil. Agri. 36(3), 369-378.

\section{Figures}

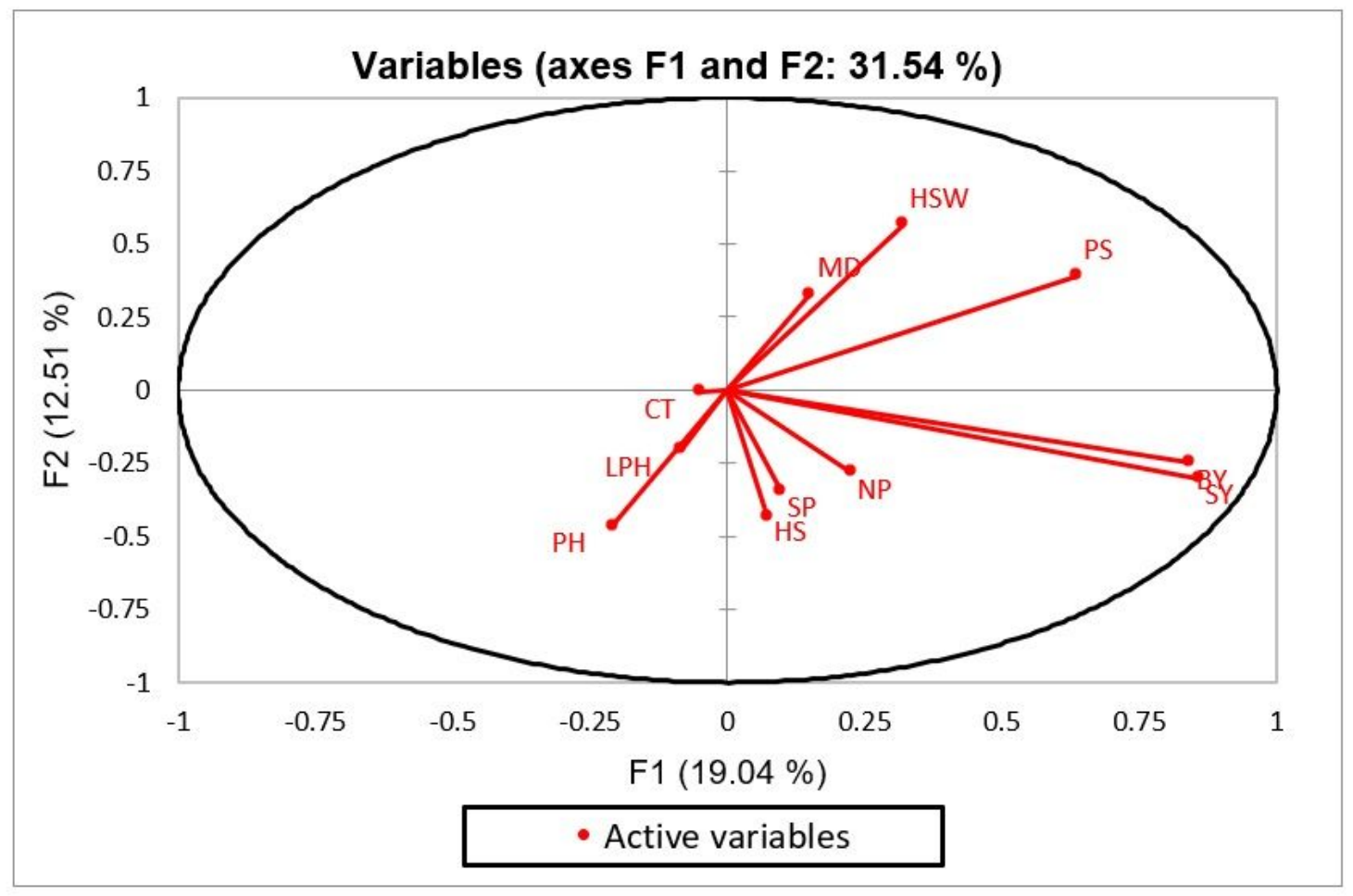

Figure 1

Principal component analyses for quantitative traits of lentil grown during 2018 


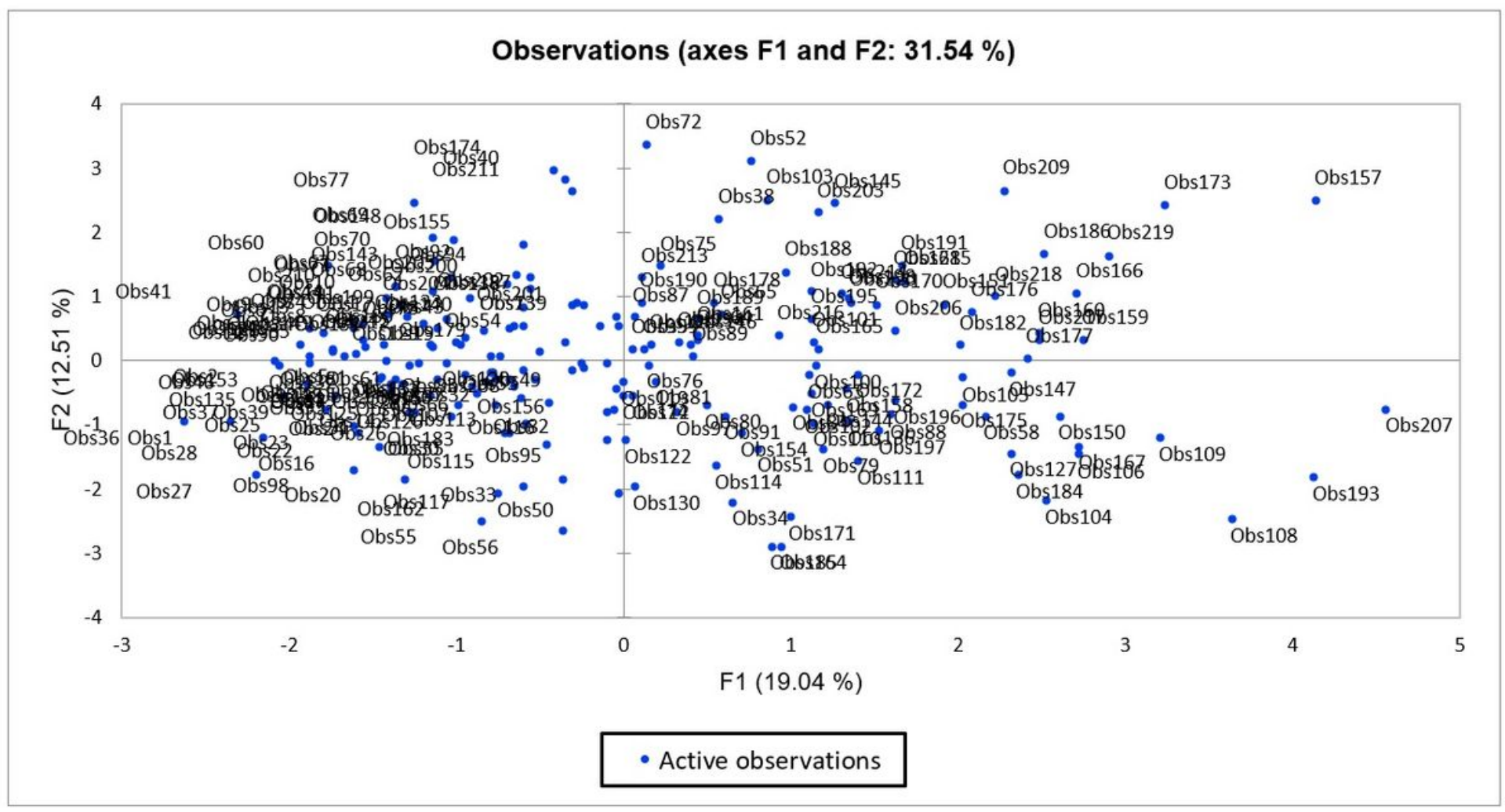

Figure 2

scattered plot of PCA for lentil genotypes grown in 2018

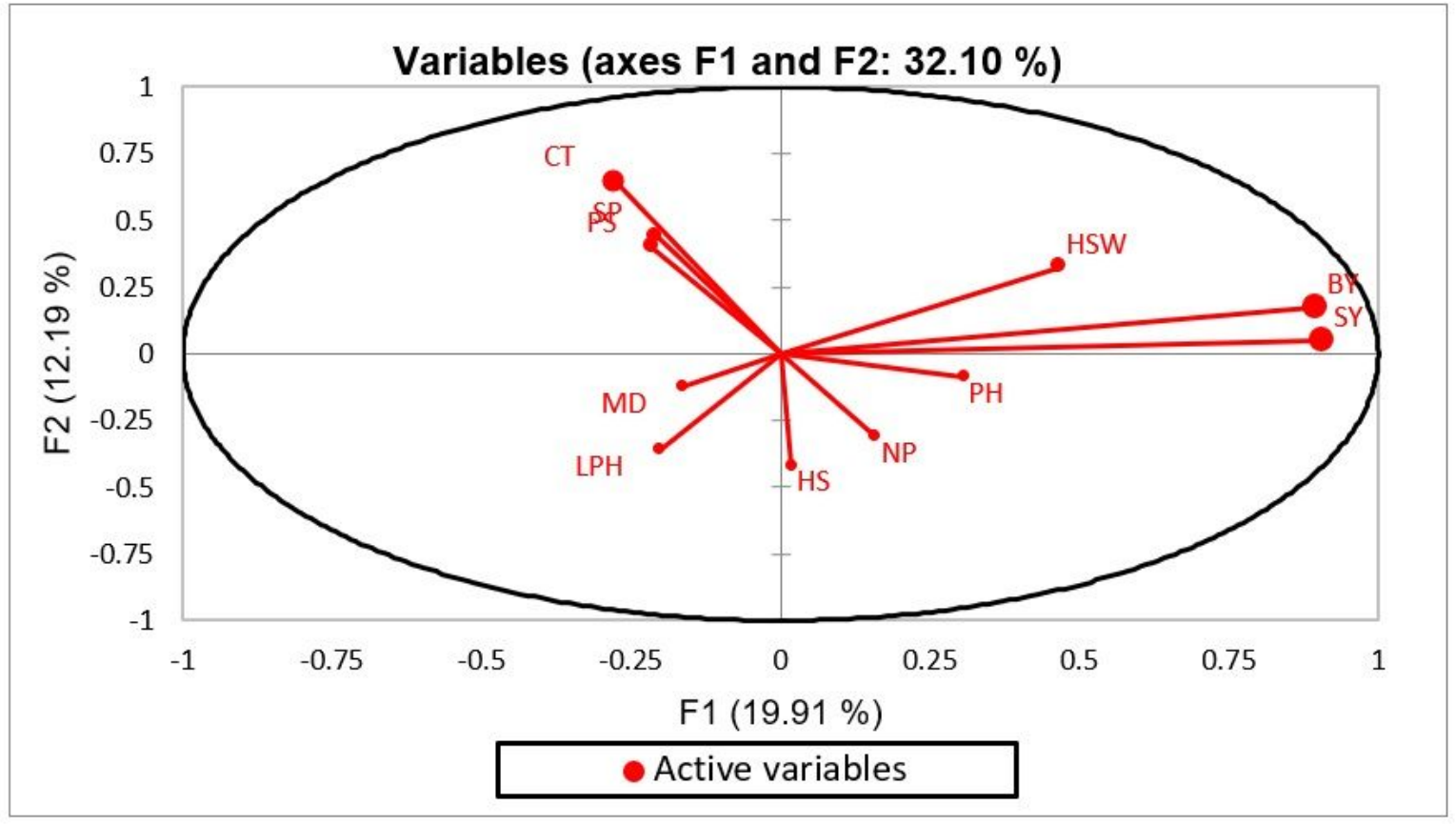

Figure 3

Principal component analysis for quantitative traits of lentil grown in 2019 


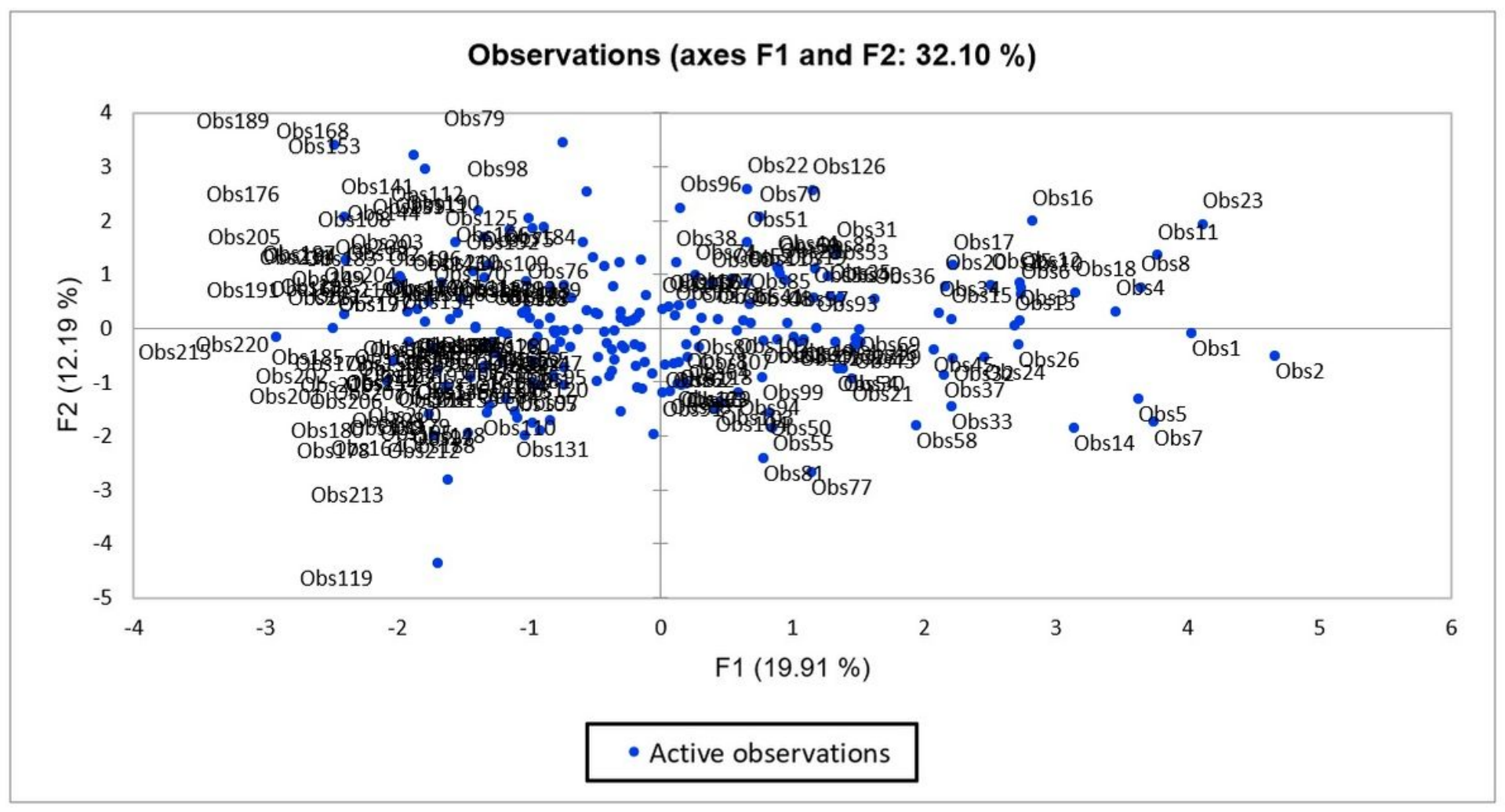

Figure 4

Scattered plot of PCA for lentil genotypes grown in 2019 


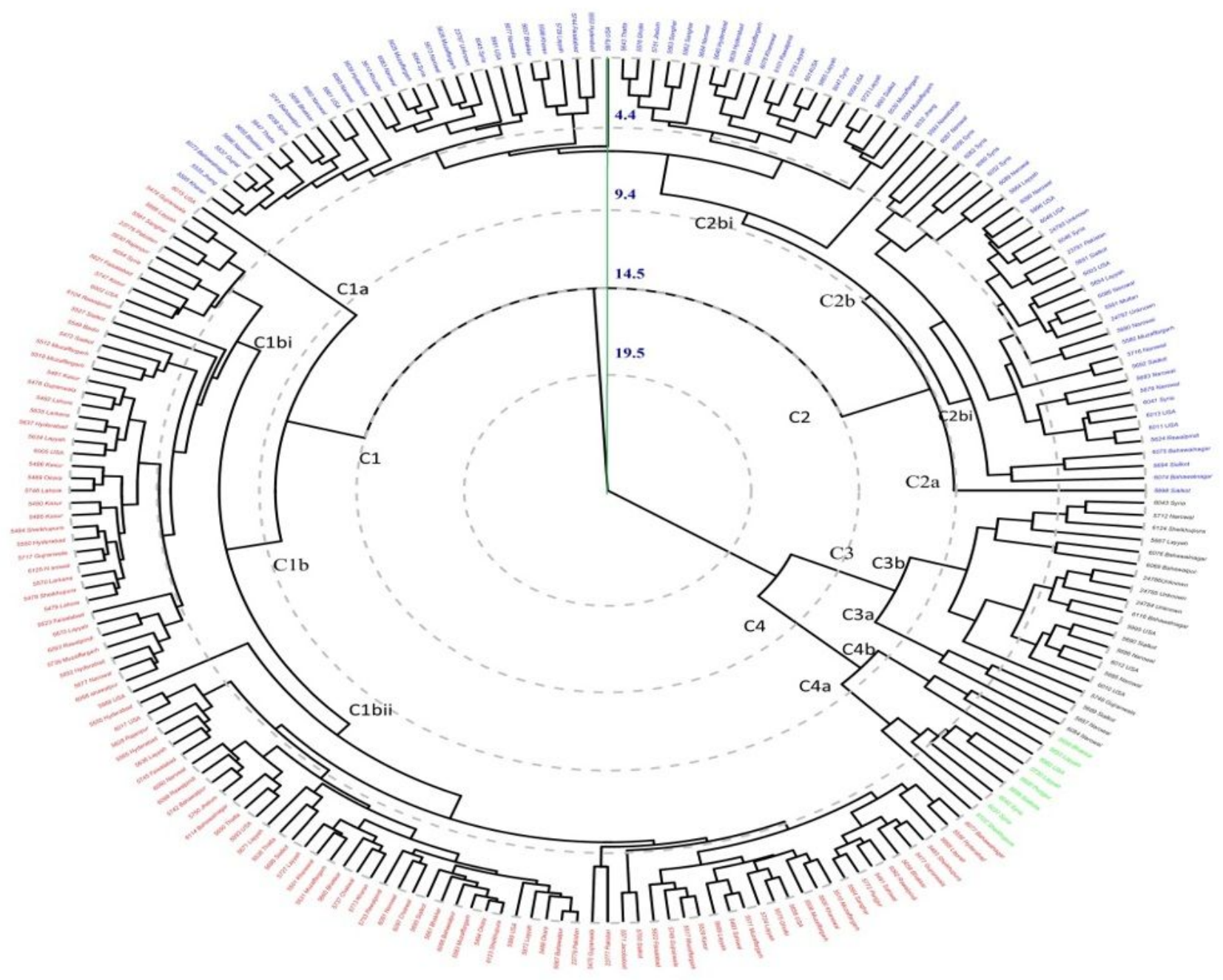

Figure 5

Hierarchical dendrogram showing genetic diversity of lentil genotypes constructed by agro-morphologic data (2018) 


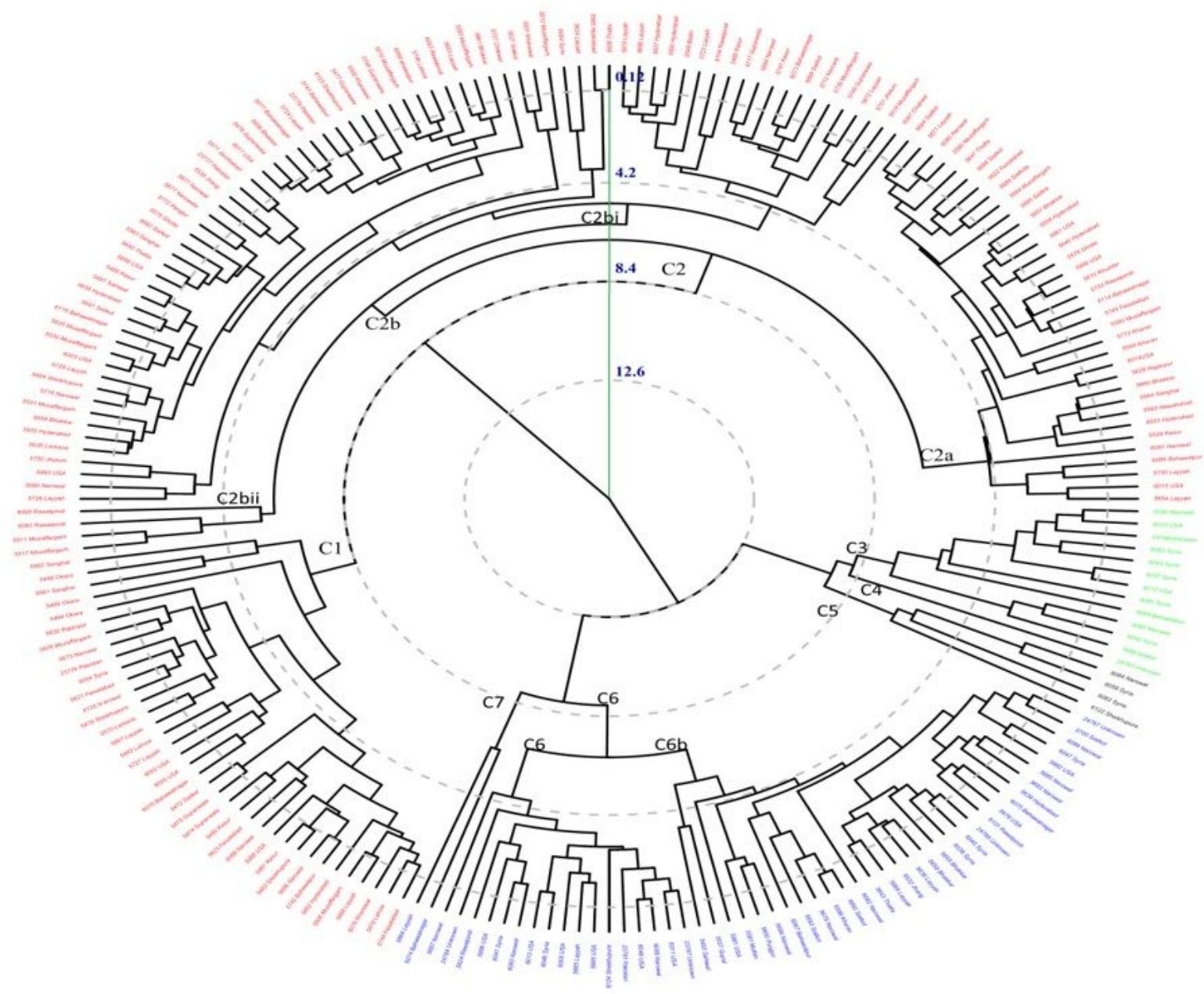

Figure 6

Hierarchical dendrogram showing genetic diversity of lentil genotypes constructed by agro-morphologic data (2019) 


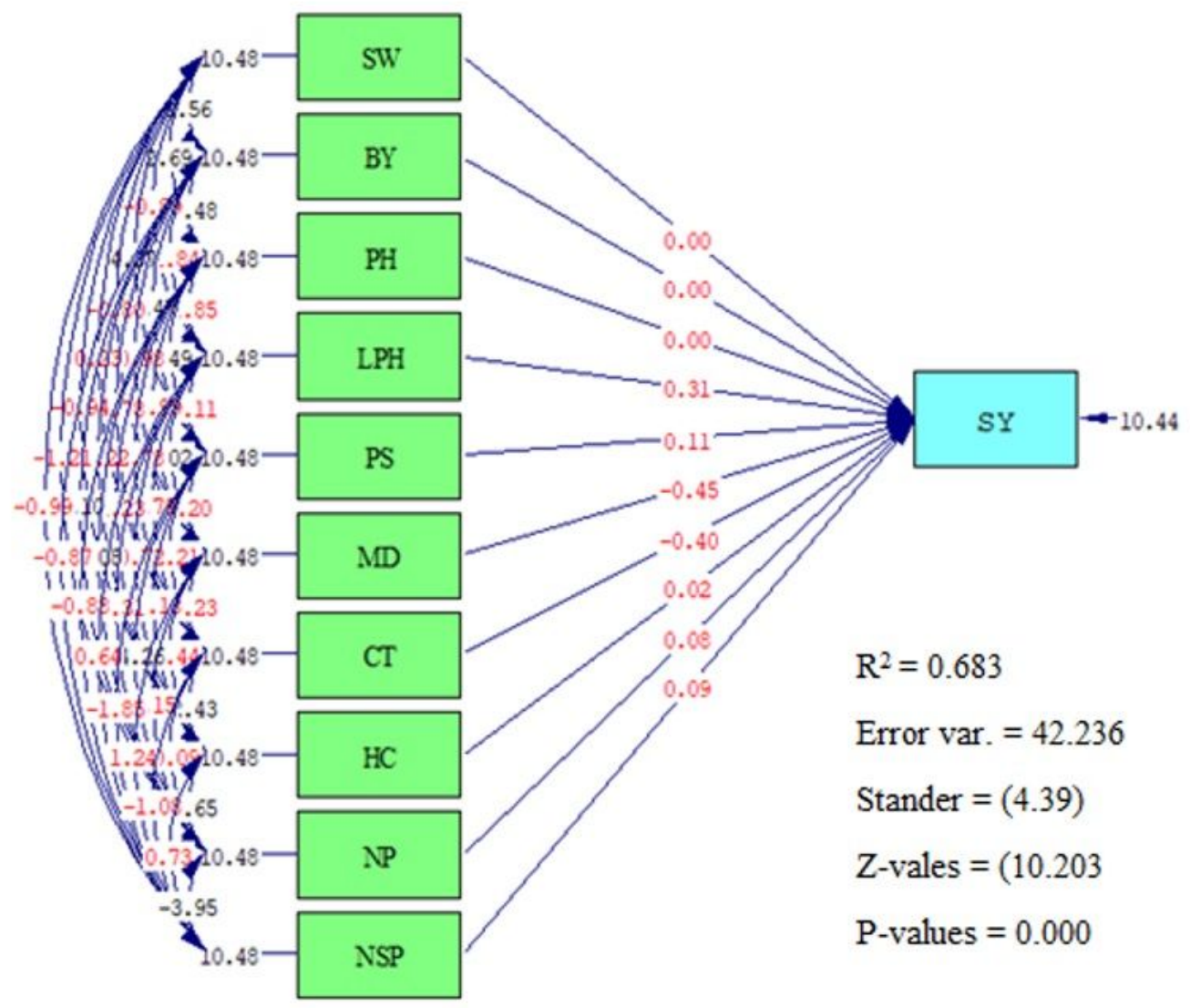

Chi- square $=0.00, \mathrm{df}=0, \mathrm{P}$-value $=1.00, \mathrm{RMSEA}=0.00$

\section{Figure 7}

Structural Equations of model for seed yield (SY)

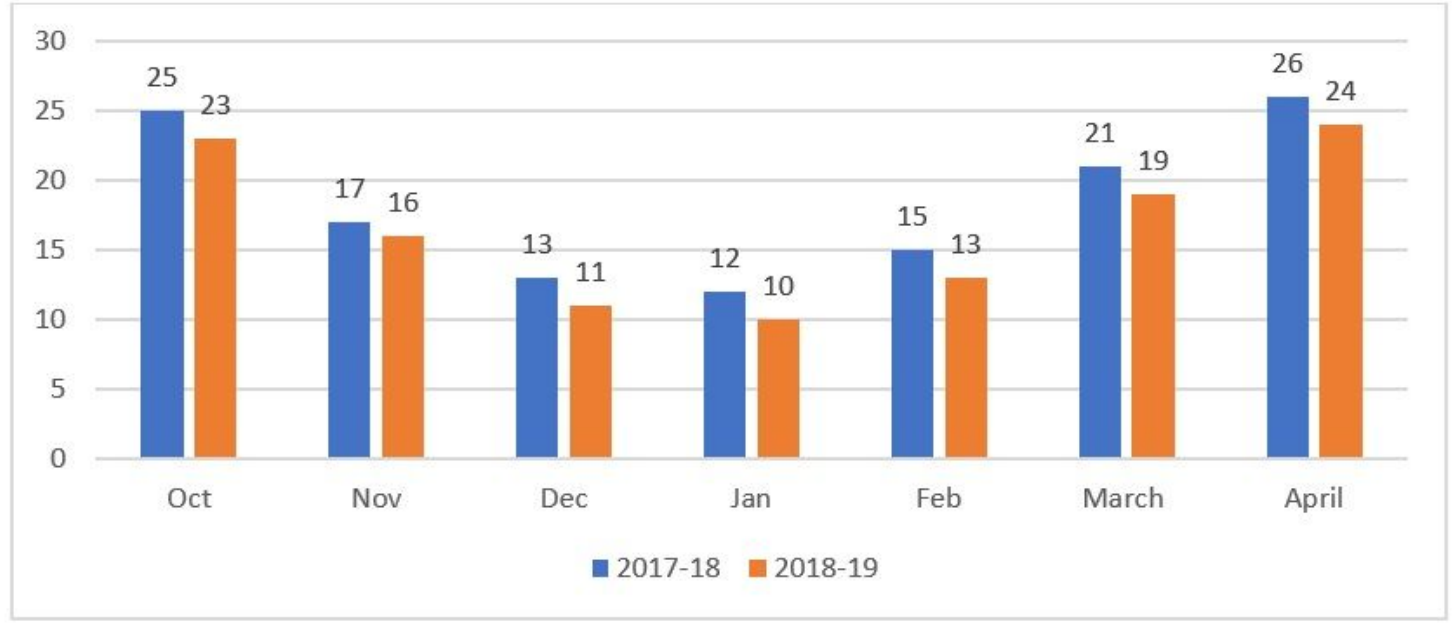

\section{Figure 8}

Average temperature during cool-season, 2018 and 2019 in Islamabad, Pakistan 